Review

\title{
Highlights in nanocarriers for the treatment against cervical cancer
}

\author{
Kaila P. Medina-Alarcón ${ }^{\mathrm{a}, 1}$, Aline R. Voltan ${ }^{\mathrm{b}}$, Bruno Fonseca-Santos ${ }^{\mathrm{c}, 1}$, Isabela Jacob Moro ${ }^{\mathrm{c}}$, \\ Felipe de Oliveira Souza ${ }^{a}$, Marlus Chorilli c,*, Christiane Pienna Soares ${ }^{a}$, André Gonzaga dos Santos ${ }^{\mathrm{d}}$, \\ Maria J.S. Mendes-Giannini ${ }^{a}$, Ana M. Fusco-Almeida ${ }^{\mathrm{a}, *}$
}

a Department of Clinical Analysis, Mycology Laboratory and Nucleus of Proteomics, São Paulo State University (UNESP), School of Pharmaceutical Sciences, 14800-903 Araraquara, SP, Brazil

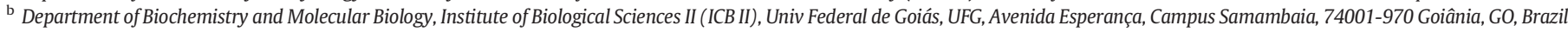

c Department of Drugs and Medicines, São Paulo State University (UNESP), School of Pharmaceutical Sciences, 14800-903 Araraquara, SP, Brazil

d Department of Natural Active Principles and Toxicology, São Paulo State University (UNESP), School of Pharmaceutical Sciences, 14800-903 Araraquara, SP, Brazil

\section{A R T I C L E I N F O}

\section{Article history:}

Received 21 June 2017

Received in revised form 10 July 2017

Accepted 13 July 2017

Available online 15 July 2017

\section{Keywords:}

Cervical cancer

Human papillomavirus

Nanocarriers

Nanotechnology

Drug delivery

Gene delivery

\begin{abstract}
A B S T R A C T
Cervical cancer is the second most common malignant tumor in women worldwide and has a high mortality rate, especially when it is associated with human papillomavirus (HPV). In US, an estimated 12,820 cases of invasive cervical cancer and an estimated 4210 deaths from this cancer will occur in 2017. With rare and very aggressive conventional treatments, one sees in the real need of new alternatives of therapy as the delivery of chemotherapeutic agents by nanocarriers using nanotechnology. This review covers different drug delivery systems applied in the treatment of cervical cancer, such as solid lipid nanoparticles (SNLS), liposomes, nanoemulsions and polymeric nanoparticles (PNPs). The main advantages of drug delivery thus improving pharmacological activity, improving solubility, bioavailability to bioavailability reducing toxicity in the target tissue by targeting of ligands, thus facilitating new innovative therapeutic technologies in a too much needed area. Among the main disadvantage is the still high cost of production of these nanocarriers. Therefore, the aim this paper is review the nanotechnology based drug delivery systems in the treatment of cervical cancer.
\end{abstract}

(c) 2017 Elsevier B.V. All rights reserved.

\section{Contents}

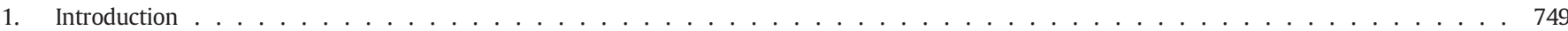

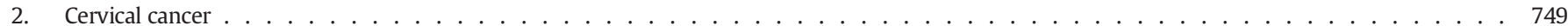

3. Nanotechnology-based drug delivery systems . . . . . . . . . . . . . . . . . . . . . . . . . . . . . . . . . . . . . . . . 749

3.1. Lipid-based nanocarriers . . . . . . . . . . . . . . . . . . . . . . . . . . . . . . 750

3.1.1. Solid lipid nanoparticles. . . . . . . . . . . . . . . . . . . . . . . . . . . . . . . . 750

3.1.2. Liposomes. . . . . . . . . . . . . . . . . . . . . . . . . . . . . . . . 751

3.1.3. Nanoemulsions . . . . . . . . . . . . . . . . . . . . . . . . . . . . . . 753

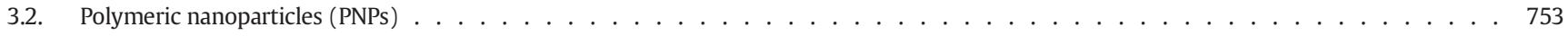

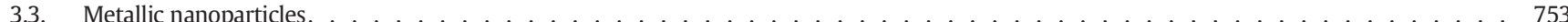

3.4. Inorganic nanoparticles . . . . . . . . . . . . . . . . . . . . . . . . .

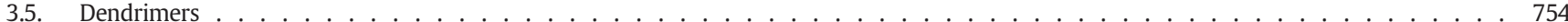

3.6. Micelles . . . . . . . . . . . . . . . . . . . . . . . . . . . . . . . . . . . . . . . 754

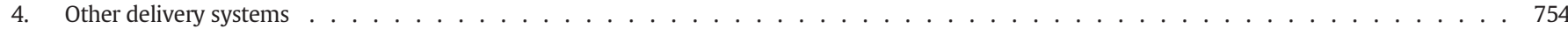

4.1. Vaccines. . . . . . . . . . . . . . . . . . . . . . . . . . . . .

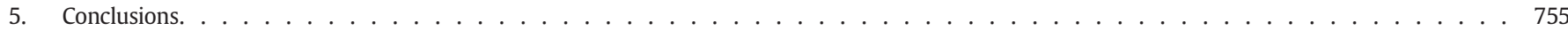

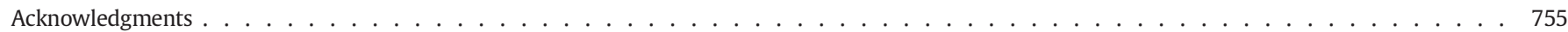

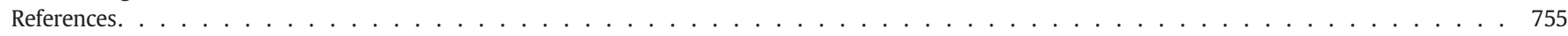

\footnotetext{
* Corresponding authors at: School of Pharmaceutical Sciences, São Paulo State University (UNESP), Rodovia Araraquara-Jaú, km 1, 14800-903 Araraquara, SP, Brazil. E-mail addresses: chorilli@fcfar.unesp.br (M. Chorilli), almeidaf@fcfar.unesp.br (A.M. Fusco-Almeida).
}

1 These authors contributed equally to this work. 


\section{Introduction}

Cervical cancer is malignant carcinoma type of cancer originate in cervix region. The cervix is the narrow portion of the uterus where it joins with the top of the vagina. Most cervical cancers are squamous cell carcinomas, arising in the squamous epithelial cells that line the cervix. Approximately, 500,000 new cases of cervical cancer are diagnosed each year, with 280,000 deaths worldwide, making cervical cancer the second most common malignancy affecting women worldwide [1]. Clinical, epidemiological, and molecular data associate high-risk HPV infection with cervical cancer development [2].

Chemotherapy uses anti-cancer drugs that are injected into a vein or given by mouth by patients. These drugs enter the bloodstream and can reach all areas of the body, making this treatment useful for killing cancer cells in most parts of the body [3]. In recent years, drug delivery systems have been developed, along with anticancer agents for those systems based on the concept of achieving a better clinical response and tolerability $[4,5]$. From the aspect of pharmacokinetics, in particular drug distribution, these may cause low bioavailability of the anticancer drug at the site of action as well as high organ toxicity limiting the maximum tolerated dose [6].

Some important technological advantages of drug delivery systems include prolonged half-life, improved distribution, increased circulation time of the drug, controlled and sustained release of the drug, versatility of route of administration, increased intercellular concentration of drug [7] and a enhances the bioavailability of the poorly soluble drugs [8-10].

Liposome technology research culminated in 1995 in the U.S. Food and Drug Administration (FDA) approval of Doxil®, the first FDA-approved nanodrug [11]. After, other systems were approved as medicines and these commercialized drug delivery systems are listed in Table 1.

The effectiveness of a treatment can be increased by incorporating nanotechnology-based drug delivery systems. Some of these new platforms, which aim to improve the bioavailability, pharmacokinetics, and pharmacodynamics of drugs while reducing their side effects, or improving the selectivity in the tumor cells are discussed in this review.

\section{Cervical cancer}

Uterine cervical cancer is the second most common malignant tumor in women worldwide and presents a high mortality rate, especially in developing countries [19-21]. According to Kessler [22], cervical cancer has an incidence of 527,624 women/year, resulting in 265,672 deaths. In addition, cervical cancer accounts for $4 \%$ of the cases of cancer diagnosed in the world. About $84 \%$ of cervical cancer cases occur in less developed countries, such as Africa, Latin America and the Caribbean.

In Brazil it is the second most frequent in women population and the incidence and mortality, according to Brazilian Cancer Foundation [23], is, approximately, 530,000 new cases and 275,000 deaths each year in young women [24].

Cervical cancer is associated with high-risk human papillomavirus (HPV) and is responsible for causing benign lesions (genital warts or papilloma) or malignant lesions. HPV has been associated with more than $90 \%$ of cervical and anal cancers, $70 \%$ of the vaginal and vulvar cancers, caused by high-risk HPV, such as types 16 and 18 [25,26].
HPV is a public health problem that primarily affects undeveloping countries, where the population with low social status and poor hygiene habits becomes the main focus of viral infection that progresses to malignancy [19]. Infection with high-risk oncogenic subtypes of HPV is the major risk factor for the development of malignant lesions in the cervix. Although HPV infection may be the triggering factor, studies show that a linkage between genetic factors and immune functions are correlated to cervical carcinogenesis and infection by the major subtypes of high-risk [27].

Over 200 types of HPV have been isolated, and there is no doubt that there are other types that have not been identified. HPV leads to large epithelial lesions, mostly benign, such as warts or papillomas, with low malignant potential. A small fraction of people infected with the type of high-risk HPV will develop cancer, which usually arise many years after initial infection [28]. There are about 30 types of HPV and genital mucosa divided into low risk (types 6, 11, 42, 43 and 44) and high risk that are associated with precancerous lesions (types 16, 18, $31,33,35,45,51,52$ and 56 ), according to their presence in malignant lesions of the cervix [29].

Only a small number of women with chronic HPV infection can progress and develop disease [30]. In addition to HPV infection, other factors can trigger cervical cancer, such as malignant and invasive phenotypic factors, smoking and benzo[a]pyrene, BaP carcinogenic smoke [30,31].

HPV proteins, particularly E6 and E7, integrate DNA viral genes (antigens) into human DNA which are responsible for the development of malignant form and tumor growth, for this reason the development of vaccines against this type of proteins [32].

Three main methods are used in the treatment of tumors: surgical procedures, radiotherapy and chemotherapy, and these can be used with curative, palliative or prophylactic purposes, alone or combined [33-36].

The surgical procedure is very particularly between patients since it depends on the age, size, stage of disease and the patient's response to post-surgical. Radiotherapy combat the disease by ionizing radiation, which depends on the characteristics of cancer and patient being difficult to control damage to any adjacent normal tissue cell. Currently, it is common the use of combined chemotherapist to enhance the desired effect and to low the toxicity.

Recently, two prophylactic vaccines against HPV, Gardasil@ and Cervarix ${ }^{\circledR}$ have demonstrated efficacy as preventive vaccines, 2 which act to produce antibodies against HPV serotypes types 6, 11, 16 and 18 (Gardasil@) and 16, 18 (Cervarix 16 and 18) [37-39].

However, these conventional treatments are very aggressive or nonspecific [234]. Currently, cancer research focuses on improving cervical cancer therapy by focusing on other treatment such as the delivery of chemotherapeutic agents by nanocarriers using the nanotechnology [40-42].

\section{Nanotechnology-based drug delivery systems}

Nanotechnology has offered many advances in the area of science especially in the area of pharmaceutical nanotechnology. Pharmaceutical and Materials sciences leads to the innovation of drug delivery thereby improving the pharmacological activity, reducing toxicity and

Table 1

Approved drugs commonly referred to as drug delivery systems.

\begin{tabular}{|c|c|c|c|c|c|}
\hline Drug & Delivery system & Proprietary name & Indication & Approval (year) & Reference \\
\hline Doxorubicin & Liposome & Doxil® & AIDS-related Kaposi's sarcoma & 1995 & {$[12,13]$} \\
\hline Daunorubicin & Liposome & Daunoxome ${ }^{\circledR}$ & AIDS-related Kaposi's sarcoma & 1996 & {$[14]$} \\
\hline Amphotericin B & Liposome & Ambisome ${ }^{\circledR}$ & Antifungal agent & 1997 & {$[15]$} \\
\hline Cytarabine & Liposome & Depocyt $\AA$ & Lymphomatous meningitis & 1999 & {$[16]$} \\
\hline Paclitaxel & Albumin-conjugated & Abraxane ${ }^{\circledR}$ & Metastatic breast cancer & 2005 & [17] \\
\hline Vincristine & Liposome & Marqibo® & Acute lymphoblastic leukemia & 2012 & [18] \\
\hline
\end{tabular}

a Food and Drug Administration (FDA) in U.S. 
improving the physicochemical characteristics to improve the solubility and the stability of drugs [43-46].

In recent years, nanotechnology has contributed as excellent platform for the treatment of cancer exhibiting efficient entrapment of drugs incorporated in the nanocarriers, reducing the toxic effects of drugs and targeting or delivery in the site of action, thus improving the bioavailability of drugs [47,48]. Thereby, several types of nanocarriers have shown an interest in the treatment of cervical cancer, these systems have the capacity to encapsulate and release drugs, vaccines, genes, proteins, etc., with different nanocarriers, for example solid lipid nanoparticles (SLNs), liposomes, nanoemulsions, polymer nanoparticles (PNPs) and others [46,48-50] (Fig. 1).

The enhanced permeability and retention (EPR) effect is a concept by which nanocarriers of certain sizes (typically liposomes, nanoparticles (NPs), and others) tend to accumulate in tumor tissue much more than normal tissues [51-55]. The general explanation of this phenomenon is that, in order for growth of tumor cells, they must stimulate the production of blood vessels in the tumor microenvironment [56] (Fig. 2). They are poorly aligned defective endothelial cells with wide fenestrations, lacking a smooth muscle layer, or innervation with a wider lumen, and impaired functional receptors for angiotensin II [57,58]. Furthermore, tumor tissues usually lack effective lymphatic drainage [58].

The EPR effect is further enhanced by many pathophysiological factors involved in enhancement of the extravasation of macromolecules in solid tumor tissues. The EPR effect is important for nanocarriers' delivery to cancer tissue [59]. The EPR effect helps to carry these systems and spread inside the cancer tissue [60].

\subsection{Lipid-based nanocarriers}

Lipid nanocarriers are lipid-based nanocarriers have a great potential for solubilizing, encapsulating and administering drugs with a potential to improve drugs absorption thereby contributing with their bioavailability and minimizing side effects [61,62]. For synthesis of these nanocarriers the most materials are used, as biocompatible lipids like phospholipids, cholesterol and triglycerides, with characteristics of biocompatibility and biodegradability. Among the lipidic nanocarriers, the use liposomes in the cancer treatment, solid lipid nanoparticles (SLNs), nanostructured lipid carriers (NLCs) and lipid polymer hybrid nanoparticles (LPN) can also be used for this purpose [63].

\subsubsection{Solid lipid nanoparticles}

Solid lipid nanoparticles (SLNs) emerged as a class of colloidal drug transporters in the early 1990s [64] with a widely used application in drug delivery used in clinical medicine [65]. SLNs are the first generation of solid lipid matrix systems on the nanometric scale well tolerated by the in vivo systems, because they are aqueous colloidal dispersions whose solid matrix forms biodegradable lipids [66-68]. Among these solid lipids are alba wax, carnauba wax, saturated glycerol esters, palmitic palmitate, stearic acid, beeswax PEG-8, cetyl palmitate and glyceryl dibehenate [69-71].

The advantages of using these nanocarriers are increase drug solubility, dose reduction, improving the stability due to its lipid matrix having the ability to protect the chemically unstable chemicals, as modulate its drug release, to provide binding and internalization in the tumor cell, this active targeting can improve SLNs distribution within the tumor vasculature and MDR cells [63,72]. This type of systems has limitations due to low loading capacity of the drug and premature expulsion of the drug during storage $[73,74]$.

The size of NPs and their volume provide that small NPs have capacity of encapsulating drugs on the surface on the hand, the modification with targeting ligands on surface of them increases the selectivity of the target and the release of the drug into tumor cells. Thus, these types of NPs can be ideal for targeting to cancer tumors for increasing of retention in the tumor area $[75,76]$. Other advantage is the small dimensions of these NPs permit the protection of the drug and facilitate administration by parenteral route (e.g. intravenous) and oral route, however the contact with gastrointestinal fluids has been a critical problem due to

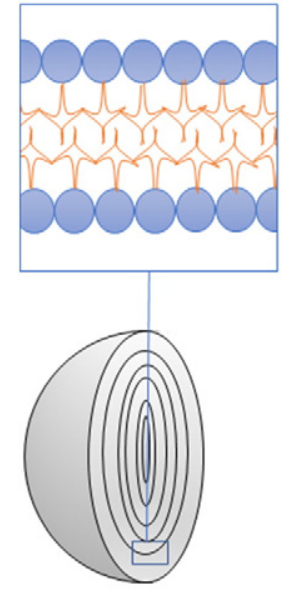

Liposomes

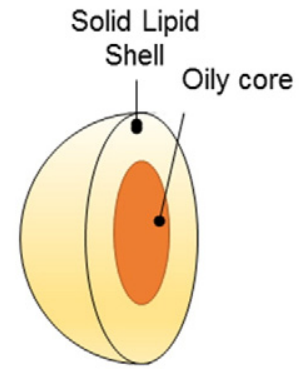

\section{Nanostructured Lipid Carriers}

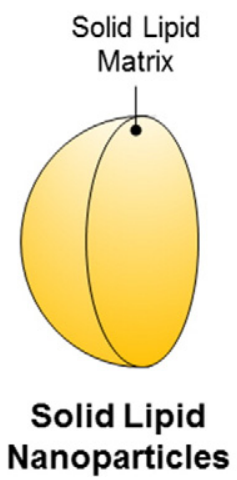

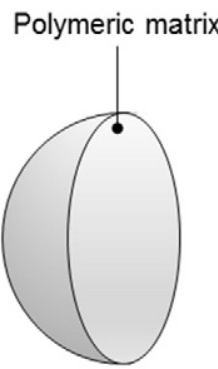
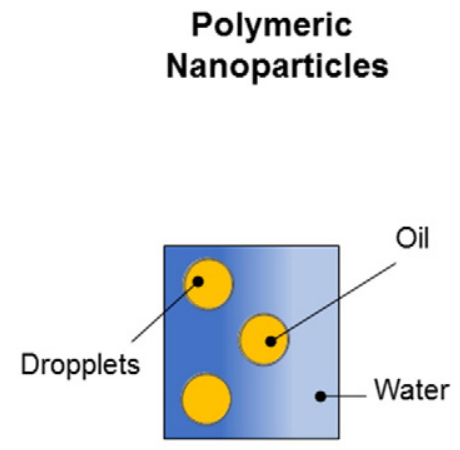

Microemulsions

Fig. 1. Schematic representation of nanostructured drug delivery systems. 


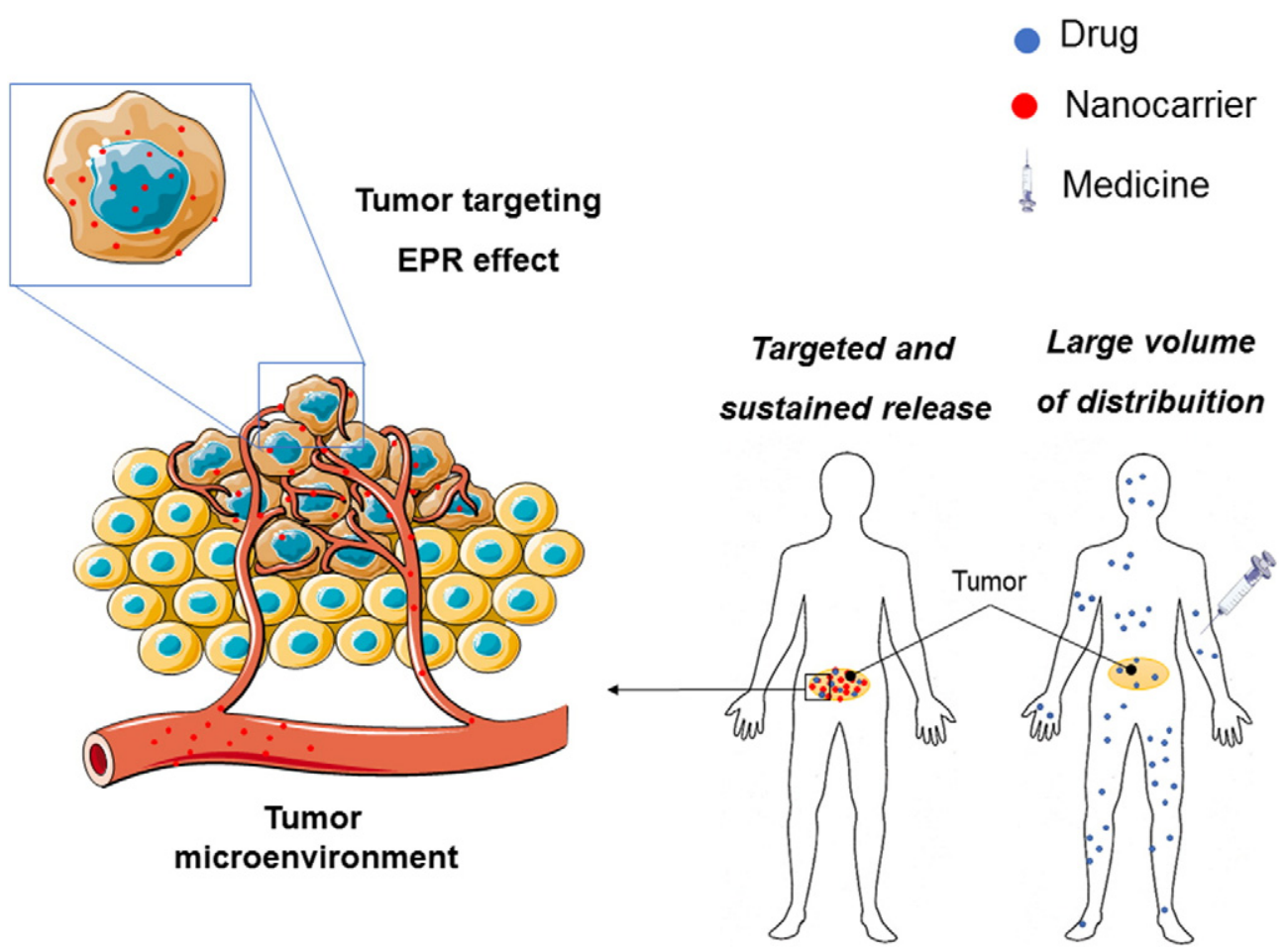

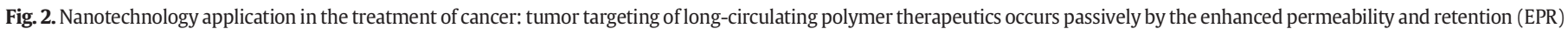

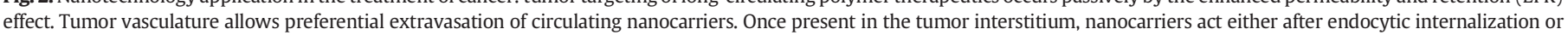
extracellularly.

the particle size which maximizes the surface area for enzymatic degradation, for example, and it has an impact for drug stability [64,77].

Liu et al. [78] designed a novel pro-drug docetaxel-loaded nanostructured lipid carrier (DTX-NLC), with the aim of reducing toxicity and improving therapeutic efficacy. The cytotoxicity assays against A549 cells induced greater apoptosis and more G2/M uptake. The inhibition rates of DTX-NLC (10 mg/kg and $20 \mathrm{mg} / \mathrm{kg}$ ) were $42.74 \%$, $62.69 \%$ and $90,36 \%$, respectively, indicating that DTX-NLC could more effectively inhibit tumor growth.

Other study, NPs were developed. (TOS-CDDP) (TAT-PTX/TOS-CDDP SLNs) with co-administration of paclitaxel (PTX) and $\alpha$-tocopherol succinate-cisplatin prodrug (TOS-CDDP) -cisplatin prodrug objective of achieving synergistic tumor activity against cervical cancer, achieving satisfactory results of internalization in HeLa cells and showing a synergistic effect on suppression of cervical tumor cell growth with high tumor tissue accumulation, superior antitumor efficiency and low in vivo toxicity [79].

Hyaluronic acid (HA) and pluronic 85 (P85) coated solid lipid nanoparticles (SLN) loaded with paclitaxel (HA-PTX-P85-SLN), with the aim of improving the antitumor efficacy in cervical cancer-bearing mice, the results by HA-PTX-P85-SLN showed $88.2 \%$ of entrapment efficiency (EE) and $4.9 \%$ of drug loading capacity (LC), with prolonged release profile when compared to the free drug up to 5 times [48].

Paclitaxel is a chemotherapeutic agent used in the treatment of lung cancer, breast cancer, cervical cancer caused by the HPV virus, this drug is a microtubule-stabilizing and inhibits the $G_{2}$ or $M$ cell phases of the cell cycle causing the cell death $[80,81]$. Topotecan hydrochloride is a drug used in the cervical cancer treatment associated with SLNs with attractive formulation characteristics in vitro release. Studies of cytotoxicity of carcinoma cell HeLa and carcinoma human cell line ( $\mathrm{SiHa}$ ), mouse embryonic fibroblast cells (3T3-L1) and African green monkey kidney epithelial (Vero) cells in vitro were conducted. This studies revealed effect cytotoxic efficacy, biocompatibility and release profile in vitro for the developed system [82].

\subsubsection{Liposomes}

Liposomes were discovered by Bangham and his colleagues in 1965 , and in the following decades, liposomes rapidly became a useful drug carrier [83]. Liposomes are closed spherical vesicles with a central aqueous cavity surrounded by two lipid membranes formed by natural phospholipids (egg yolk lecithin and soybean lecithin), synthetic phospholipids (semisynthetic dimyristoyl phosphatidylcholine - DMPC) and cholesterol [84].

Liposomes may be formulated with innumerous phospholipids and excipients generating versatile systems that can easily be modified in the formulation and this changes in formulations parameters may affect the encapsulation capacity of drugs, the permeability, stability and liposome size and lamellarity [85].

Thus, liposomes can be prepared by various methods, such as agitation, sonication, extrusion, lyophilization, freeze-thaw process, and reverse phase evaporation, detergent depletion method, ether/ethanol injection [86,87], emulsification methods and a transmembrane $\mathrm{pH}$ gradient-driven encapsulation technique $[88,89]$. Another technique is to apply dense gas, or supercritical fluid techniques [90,91], and this techniques are eco-friendly because avoid the use of organic solvents which may be toxic to human and environment.

Different techniques and methods of preparation can form unilamellar vesicles (SUV) having diameters of 40 to $80 \mathrm{~nm}$ and large unilamellar vesicles larger than $100 \mathrm{~nm}$, multilamellar vesicles (MUV) and large unilamellar vesicles (LUV) with a size range greater than $60 \mathrm{~nm}$ [92]. Some strategies can be achieved by attaching ligands or antibodies to the surface of liposomes that bind to receptors, thus the drug is delivered in the site of action by binding receptor reducing the toxic effects on other regions not targeted [93]. The liposomes are used as strategies for administering hydrophilic or hydrophilic drugs and they allow to use in the clinic because they have a rapid distribution, however the low absorption and toxicity limit the therapeutic efficacy, in order to overcome the undesired effects liposomes appear as an alternative with cell surface receptors and active administration, and many 
liposomal formulations have been developed to release directly to specific stimuli such as $\mathrm{pH}$, heat, external magnetic field, ultrasound. However, the development of liposomes allowed introduction some products on the market [94].

Liposomes are capable of incorporating both lipophilic and hydrophilic drugs, and these systems show the reducing the toxicity and show a biocompatibility due to the similarity with the cellular membranes, thus are considered one of the most convenient systems in the treatment of cancer [84,95-97].

Hybrid systems - liposomes and chitosan particles have been used to overcome these deficiencies, the mucoadhesive, nanocarrier designed for being the advantage of this type of treatment in cervical cancer, studies. Studies $[98,99]$ have shown that the liposome-chitosan nanocarrier system has significantly increased the permeability of curcumin resulting in a superior formulation compared to conventional systems of vaginal administration phospholipid-chitosan hybrid nanoliposomes promoting cell entry for drug deliver against cervical cancer [100].

Paclitaxel (PTX) loaded multilayered liposomes assembled layer by layer positively charged liposomal to aid administration of lyophilized formulation of subsequent liposomal-chitosan coated with (PAA) anionic polyacrylic acid (PAA-PTX). This system was stable in gastrointestinal fluids simulated, the in vitro release assays demonstrated that the liposomal chitosan formulation exhibited controlled release of drug, and this formulation showed increased cytotoxicity in human cancer cells of PTX compared to PTX-liposomes [101].

Doxorubicin is an effective anticancer drug, which induces caspasedependent apoptosis in cancer cells through oxidative DNA damage due the topoisomerase II inhibition [102,103]. In order to reduce undesirable side effects of doxorubicin the use of liposomes may have the ability to target specific receptors, Sriraman et al. [104] evaluated the anticancer activity of liposomes loaded with PEGylated doxorubicin-loaded liposomes with folic acid (F), transferrin (Tf) or both (F and Tf) and the liposomes increased by up to 7 fold when compared to single ligand compounds in monolayers of human cervical carcinoma cells (HeLa). The liposomes (F) and liposomes (F and Tf) showed a tumor growth inhibition of $75 \%$ and $79 \%$, respectively, compared to the untreated group, the non-targeted liposomes showed $42 \%$ inhibition of tumor growth.

Therefore, the use of liposomes as drug delivery system for the treatment of cancer is ascending, as well as to cervical carcinomas caused by HPV infections. Studies of the use of liposomes to release drugs in cases of HPV starts around the year 90. In 1996, Lappalainen et al. [105] suggested that cationic liposomes containing antisense oligonucleotides for HPV 16 E7 mRNA could be released in CaSki cells, despite some negative points, other studies have demonstrated good results with liposome, as shown in the Table 2.

Most studies report liposomes with HPV to aim vaccine production. Cui and Huang [108] showed liposome-protamine-DNA (LPD) could be a potent vaccine carrier and/or adjuvant for many antigens due to mannan coating significantly increased the preventive and therapeutic activities of LPD/E7 (complex class I - restricted peptide antigen from HPV 16 E7 protein) with IFN- $\gamma$ release by isolated splenocytes obtained an improved response when mice were immunized with mannan-coated LPD/E7 than with LPD/E7 alone.

Daftarian et al. [117] developed a new platform for vaccine administration (VacciMax, VM), obtained good results in the eradication of tumors through the encapsulating antigens and adjuvants in multilamellar liposomes. After, the use of the DOTAP/E7-lipopeptide vaccine observed enhanced therapeutic effect for the treatment of a cervical cancer model. Mizuuchi et al. [113] described the OML-HPV (HPV 16 E6 and E7 gene plasmid containing oligomannose liposomes) was more effective than DNA vaccination using liposomes.

In the context, studies have shown that cervical cancer-specific antigens may be associated with incorporation into nanocarriers used to aid the production of antigens. This demonstrates that this association leads to a better response against the HPV 16 E7 tumor epitope and the proteins incorporated into the liposomes, results in potentially safer proteins with a strong immune response, with tumor regression studies evaluated in vivo [108,118].

Another drug used in the treatment of cancer is lipoplatin and this drug reduced systemic toxicity, however it presents limitation the low

Table 2

Summary of liposomal nanocarriers applied in the treatment of cancer.

\begin{tabular}{|c|c|c|c|c|}
\hline Liposomes & Drugs or active ingredients & Model & Major results & References \\
\hline Liposomal AS-ODNs & Antisense oligode-oxynucleotides (AS-ODNs) & CaSki cells & Further studies are still required. & {$[105]$} \\
\hline Liposome-protamine-DNA (LPD) NPs & Cholesterol-conjugated mannan & DC2.4 cells & Enhanced anti-tumor activity & {$[106]$} \\
\hline Agarose/liposome/siRNA formulation & iRNA & Epithelial cancer cells & $\begin{array}{l}\text { Successful topical gel-based delivery of inducers } \\
\text { of RNAi to human epithelial cancer cells }\end{array}$ & [107] \\
\hline LPD (liposome-polycation-DNA) & E7 antigens & Mice & $\begin{array}{l}\text { Regressions of a model cervical cancer tumor; } \\
\text { Potent vaccine carrier and/or adjuvant for many } \\
\text { antigens. }\end{array}$ & [108] \\
\hline $\begin{array}{l}\text { siRNA of HPV } 16 \text { E6 was synthesized } \\
\text { and transfected into CaSki cells } \\
\text { by liposome }\end{array}$ & E6 and E7 antigens & CaSki cells & $\begin{array}{l}\text { The interference of HPV } 16 \text { E6 gene occurs, } \\
\text { being specific and highly efficient. }\end{array}$ & [109] \\
\hline DOTAP/E7 complex & $\begin{array}{l}\text { Peptide antigen derived from E7 } \\
\text { oncoprotein of HPV type } 16 .\end{array}$ & Mice & Antigen-specific anti-cancer activity. & {$[110]$} \\
\hline Cationic liposomes & $\begin{array}{l}\text { (si)RNA duplexes or small-hairpin } \\
\text { (sh)RNA-expressing plasmids targeting } \\
\text { the E7 genes of HPV-6b or HPV-11 }\end{array}$ & Mice & $\begin{array}{l}\text { iRNA specifically modulates expression of } \\
\text { genes for HPV-6b/11 E7, being a useful } \\
\text { method to control the condyloma } \\
\text { acuminatum. }\end{array}$ & [111] \\
\hline Biphasic vesicles & INF- $\alpha$ & Humans & $\begin{array}{l}\text { Biphasic vesicles such as INF- } \alpha \text { delivery } \\
\text { system can deliver significant levels of INF- } \alpha \\
\text { through intact skin and promote therapeutic } \\
\text { effects in patients. }\end{array}$ & {$[112]$} \\
\hline $\begin{array}{l}\text { HPV } 16 \text { E6 and E7 gene plasmid } \\
\text { containing oligomannose liposomes } \\
\text { (OML-HPV) }\end{array}$ & E6-derived peptide (E6 66-74) and E7. & - & $\begin{array}{l}\text { E6 66-74, a peptide derived from E6, can be a } \\
\text { target for immunotherapy of cervical cancer. }\end{array}$ & [113] \\
\hline $\begin{array}{l}\text { Liposomal transfection of HPV16E7 } \\
\text { SiRNA }\end{array}$ & E6 and E7 & CaSki cells & $\begin{array}{l}\text { HPV16 E7, in cases of cervical cancer, may } \\
\text { become a new target for gene therapy. }\end{array}$ & [114] \\
\hline $\begin{array}{l}\text { E6 siRNA complexed with pegylated } \\
\text { lipoplexes }\end{array}$ & $\begin{array}{l}\text { Cationic liposomes DOTAP/Cholesterol/DOPE } \\
1 / 0.75 / 0.5(\mathrm{~N} / \mathrm{P} 2.5) \text { with or without } 50 \% \\
\text { DSPE-PEG2000 }\end{array}$ & CaSki cells & $\begin{array}{l}\text { Lipoplexes pegylated anti-E6, in the release } \\
\text { of cytoplasmic siRNA has demonstrated its } \\
\text { effectiveness to cross the cell membrane. }\end{array}$ & [115] \\
\hline siRNAE7-DOPC-NPs & $\begin{array}{l}\text { E6-E7 mRNA and E7 protein using siRNAE6 } \\
\text { or siRNAE7 }\end{array}$ & Mice & Antitumor activity of siRNA-DOPC-NP & [116] \\
\hline
\end{tabular}


availability in the site of action and for this reason are developed liposomes thermosensitive (HTLC). These liposomes release the drug by heating and show significant improvements in models canine and murine and was similar to ThermoDox (Celsion Corporation, Lawrenceville, $\mathrm{NJ}$ ) for the delivery of doxorubicin $[47,119,120]$.

Several types of liposomes have been developed for specific delivery in the drug tumor as thermosensitive liposomes, sensitive liposomes at $\mathrm{pH}$ lower and echogenic liposomes (ultrasound) used for hydrophilic drugs for the drug delivery, liposomes magnetic often used with lipophilic drugs, for example paclitaxel, or diagnostic imaging, [94,121124].

Cationic liposomes are used especially like transport genes, however are reported to encapsulating substances such as curcumin acting preferentially targets the angiogenic endothelial and destroying the vascular function and limiting the metastasis, as well as curcumin there are also pre-clinical studies for cancer [125-127].

Saengkrit et al. [125] have demonstrated an improvement in cervical cancer therapy results have become successful because the formulation contains cholesterol and phosphatidylcholine that allow better penetration into the tumor. In addition, the curcumin loaded can use in the cancer therapy and reinforce the use of the curcumin minimized the accumulation compared to drug free and reducing the toxic effects.

\subsubsection{Nanoemulsions}

Nanoemulsions are heterogeneous systems consisting of an oil phase dispersed into aqueous phase stabilized by a surfactant or emulsifying agents $[128,129]$. The emulsifying agents are amphiphilic surfactants which have the ability to reduce the interfacial tension between the immiscible liquids (oily phase and aqueous phase) in the interface [130].

Studies in the literature show that the tumor tissue is needed a good vascularization, so when there is a deficiency no formation of an aberrant basal membrane and fenestrations so as not functionality of lymphatic vessels leads to poor lymphatic drainage at the tumor site, resulting in an increase in permeability at the tumor site with vascular $380-780 \mathrm{~nm}$ pore size of this effect has led to the development of agents nanotherapeutic [54]. Nanodevices with a size less than $10 \mathrm{~nm}$ can be filtered by the kidney and the particles rapidly above $100 \mathrm{~nm}$ may be recognized by cells of the mononuclear phagocyte system (MPS) [131]. The charges the surface of a nanoemulsion are also a determinant neutral or negative system some authors have referenced with better therapeutic activity and the hydrophobicity are important at system aspects delivery efficiency $[123,130]$.

Nanoemulsions have sizes which may range from 50 to $200 \mathrm{~nm}$ those having smaller droplet size provides a large surface area in this way a more rapid and uniform absorption of the drug administration [132]. Thus, they are excellent vehicles for the encapsulation of drugs by improving the delivery and decreasing the toxicity of the same [133].

Nanoemulsions with sizes less than $200 \mathrm{~nm}$ and with a negative surface charge prevent the coalescence of the droplets during the formulation and have a half-short life due to opsonization of mononuclear phagocyte system (MPS) and due this characteristic they can coated with polymers to avoid recognition of MPS cells [134,135].

Another strategy to increase the retention time in the tumor is to increase the chain of polyethylene glycol (PEG) Another strategy is to attach to specific component for target identification in this way allows specific delivery of the same tumor [130,136-138]. The nanoemulsions are commonly prepared with excipients approved by the Food and Drug Administration (FDA), and can be produced in large quantities by high pressure or mechanical extrusion process.

Melphalan is an anticancer drug that has been used in the treatment of ovarian cancer, breast cancer and multiple myeloma, this medicine is used in pharmaceutical tablet and injectable forms [139]. Pooja Rajpoot and colleagues (2012), incorporated melphalan in a nanoemulsion, these systems exhibited higher values of bioavailability in the ovary in comparison to the drug free, also showed a. The stability of the drug in the formulation was carried out at $40 \pm 2{ }^{\circ} \mathrm{C}$ and $75 \pm 5 \%$ for 3 months and showed above $98 \%$ of the drug content. This nano-emulsion showed 4.83 folds increase in bioavailability of the drug in comparison to drug suspension, which may enhance the clinical application of promising drugs incorporated into a nano-emulsion [133].

Due to the limitations of drugs such as cisplatin applied in the treatment of cervical cancer [130], the endothelial growth factor (EGFR) binding peptide was bound to the surface of the nanoemulsion to improve targeting ability and gadolinium providing the diagnostic capacity for an EGFR-overexpressed imaging therapy in ovarian cancers [140]. The pharmacokinetic study showed prolonged levels of platinum and gadolinium in the blood with nanoemulsions in mice. Nanoemulsions exhibited less toxicity and increased the survival time of mice compared to an equivalent treatment of cisplatin [140].

\subsection{Polymeric nanoparticles (PNPS)}

PNPs are particle with size range of 1-100 nm [141,142] with numerous advantages, as protection against enzymatic degradation, controlled release and high penetration capacity [143]. Into PNPs is possible loading molecules, as antibodies, DNA, RNA, and its allow a specific interaction in the specific targets, as cancer cells [79,144,145]. However, there are some disadvantages as the degradation (e.g. enzymatic) and high cost to manufacture $[65,143]$.

PNPs are classified in nanospheres and nanocapsules and can be builded by polymers, as polyacrylamide, polyacrylate [146], gelatine [147], chitosans [148], polylactic acid [149] and others materials [46].

PNPs was used as antibacterials and chemotherapics in the treatment of cervical cancer. Silver nanoparticles using aqueous dispersion of chitosan-graft-poly (acrylamide) as reducing agent and polyethylene glycol (PEG) as agent stabilizer. The synthesized nanoparticles showed significant cytotoxicity to human cervical HeLa cancer cells and the inhibitory concentration at $50 \%$ cell death (IC 50) was found to $8 \mu \mathrm{g} / \mathrm{mL}$ [150].

\subsection{Metallic nanoparticles}

Metallic NPs are very versatile tools for biomedical applications, including the distribution of targeted drugs, gene delivery and used in the diagnosis [151]. There is great interest to study the silver NPs [152, 153] for the use of the biochemical and biochemical materials in the biomedical field, such as immunoassays, diagnosis and delivery of drugs in cancer therapy [154]. Silver NPs may be associated with extract (Styrax benzoin) may be used in dressings in the treatment of chronic wounds [155]. The study of gold NPs has gained interest due to its medical applications, such as nanocarriers [156,157]. Due to their physical, chemical and photometric properties, they are applied in cancer therapy as drug transporters such as doxorubicin, a drug widely used in the treatment of cancer, or with other drugs for penetrating tumor cells, thus decreasing the dose of the drug and improving the response to tumor cells [158].

NPs binded with resveratrol (GNPs) generating supramolecular nanoassemblies of GNPs and doxorubicin (Dox), and these complex Dox-GNPs have high stability and showed high anticancer activity in human cervical carcinoma cell lines. These results show strong evidence that novel drug delivery vehicles have applications for diagnosis and treatment of cancer [159].

The titanium widely used in medicine because of its biological properties is widely used in the pharmaceutical and cosmetic industry [ 160 , 161]. Studies showed that exposure to UV radiation of titanium dioxide $\left(\mathrm{TiO}_{2}\right)$ NPs produces reactive oxygen species (ROS) [162], and the cytotoxic and apoptosis inducing effect was reported in human lymphoblastic cells, and these mechanism of apoptosis for these NPs is still unknown [163]. $\mathrm{TiO}_{2} \mathrm{NPs}$ were desmonstred to increase caspase 3 activity in cervical carcinoma cells (HeLa cells), increasing auto-catalysis by inhibiting the growth of cervical carcinoma cells [164]. $\mathrm{TiO}_{2}$ NPs may be associated with UV applications, resulting in $90 \%$ death of the cancer cells (HeLa cells) [165]. 


\subsection{Inorganic nanoparticles}

The copper oxide (CuO) NPs have potential in the treatment of cervical cancer, lungs, among others. A study showed cytotoxicity against four lineages of cancer cells, such as human breast (MCF-7), cervical (HeLa), epithelioma (Hep-2) and lung (A549) and a normal human dermal fibroblast (NHDF) cell line [166].

Zinc oxide NPs (ZnO-NPs) have photocatalytic properties and have been used in cosmetics, as sunscreens, and for the degradation of environmental pollutants. In addition, ZnO-NPs in combination with paclitaxel and cisplatin in head and neck squamous cell carcinoma (HNSCC) have been shown to induce selective cell death of the tumor for in vitro studies [167].

Barium carbonate $\left(\mathrm{BaCO}_{3}\right)$ is an important thermodynamically stable mineral of carbonates [168-170]. Used in the medical field and nanomaterials through the green synthesis of NPs that is an ecological method and does not involve expensive and dangerous chemicals that could pose a risk to health [171]. Studies report that use of NPs can induce apoptosis in tumor cells [172] and these NPs affect cell activity due to size, surface area and production of intracellular ROS [173]. Other research showed that $\mathrm{BaCO}_{3}$ NPs increased the expression of caspase-3 that promotes apoptosis [174].

\subsection{Dendrimers}

Dendrimers are monodisperse systems formed by molecular weight polyenes having a defined structure consisting of tree-like arms or branches [175-177]. Dendrimers can incorporate small guests molecules by electrostatic or hydrophobic interactions [178,179], and the drugs can be binded on their surface through polar interchanges such as amine and carboxyl groups. In some cases the surface groups are covalently modified and added sugar and drugs [180,181], for this reason the dendrimers are used in medical and biotechnological applications due to their biocompatibility $[182,183]$. Studies have shown that anticancer drugs are loaded in dendrimers and they show promise in the treatment against the tumor cells $[184,185]$.

According to Donalisio et al. [186] dendrimers of peptides consist of a nucleus with peptide branches and/or surface functional units covalently bound. A series of dimeric and dendrimeric linear peptides with basic amino acids were evaluated against the HPV, showing that the peptide dendrimer SB105-A10 was a potent inhibitor of genital HPV types (i.e. types 16,18 and 6 ) with a $50 \%$ inhibitory concentration of 2.8 and $4.2 \mu \mathrm{g} / \mathrm{mL}(0.59$ and $0.88 \mu \mathrm{M})$, and no evidence of cytotoxicity was observed. SB105-A10 can interact with immobilized heparin and heparin sulfates exposed on the cell surface and this inhibits the binding of the virus to the cell surface. Thus SB105-A10 is a major candidate for further development as an active ingredient of a topical microbicide against HPV.

Others studies with interfering RNA (siRNA) for cancer treatments, such as uterine cervix cancer, and the high-risk HPV E6 and E7 oncogenes are the primary cause of the disease. The use of the siRNA (DF3) -loaded dendrosomes show an optimal treatment and release of siRNA was observed [187]. This system shows promising use in the treatment of cancer, however in vivo studies should be conducted.

There is relevance for the use dendrimersin the treatment of cervical cancer, these systems allow the accumulation of the nanocarriers in the tumor increasing the therapeutic effect and reducing the side effects.

\subsection{Micelles}

Micellar are nanocarriers with size around or less than $100 \mathrm{~nm}$ and they are readily prepared $[188,189]$. Micelles allow a great depth of tissue penetration for targeted drug delivery and they usually disintegrate rapidly in the body. Micelles can be formed by any amphiphilic molecule, as surfactants, in aqueous media. However, conventional surfactants have a very high critical micelle concentration (CMC), a concentration beyond which the surfactant forms micelles. High CMCs implies that the micelles can dissociate upon dilution in the bloodstream or other biological fluids following dosing [190]. Due to this limitation, alternative amphiphilic materials including amphiphilic copolymers have been developed and these materials can form micellar structures in aqueous media, but at lower concentrations [191].

Micelles can be administered for most routes, such as intravascular [192-194], oral [195,196], topical [197,198] and others. Micellar formulations can be tailored for a given route of administration, adjusting the viscosity appropriately of them for topical or transdermal formulations, incorporating a mucoadhesive polymers for vaginal or rectal administration [199]. This non-invasive route of delivery provides advantages in avoiding both contact with the gastrointestinal tract and hepatic first-pass effects compared to oral route and is cosmetically more acceptable to many patients [200].

On the hand, the administration of bioadhesive thermoresponsive systems has been reported to vaginal drug delivery [201-204]. These delivery systems introduce the convenience of a single dose of dosage forms that can be applied at any time, and control release properties of drugs [205]. Besides, mucoadhesive systems provide intimate contact between a dosage form and the vaginal mucosa, which may result in drug concentration in a local area and hence high drug flux through the vaginal mucosa [206].

Environmentally sensitive formulations are systems that can alter their physical characteristics as a result of exposure to environmental changes [204] or designed systems which enable drugs to be encapsulated, targeted to a specific region and released "on demand" in response to an external stimulus, for example exposure to $\mathrm{pH}$ of vagina or temperature of body [204]. In this way, micelles with these properties for triggered delivery have been developed [207-212]. Thus, the use of externally or internally applied triggers of drug delivery to materials has significant potential for improved delivery of drugs [213].

For cancer, micelles have been extensively studied and they are proposed as drug delivery systems [208,209,214,215]. Few clinical trials are being conducted for polymeric micelles and these systems are used for improving the solubility of poorly soluble drugs such as anti-cancer drugs [192]. Recently, the advances of Molecular Biology field, the gene delivery from nanocarriers has potential because of the wide variety of genes that could be delivered and targeted to cells [189,209,216,217] for cancer therapy [218,219].

Some studies show a direct application against cervical cancer [220]. Polymeric micelles were targeted with folic acid and loaded with paclitaxel and inhibited tumor growth and caused cell apoptosis of U14 cervical cancer tumors both in vitro and in vivo [221]. Folic acid conjugated polymeric micelles loaded with a curcumin showed high anticancer activity causing significant cell population [222] and conjugation of molecules' ligand-mediated, e.g. hyaluronic acid, folic acid gave to conjugated polymeric micelles the ability to accumulate into cells resulting in better anticancer activity [223].

In vitro and in vivo experiments show that paclitaxel-loaded micelles formulations possess effective cellular uptake and potent cytotoxicity, and exhibit reduced systemic toxicity and enhanced antitumor efficacy towards human cervical tumor [224].

Folic acid-conjugated micelles had superior cytotoxicity against HeLa cells compared to non-conjugated micelles. HeLa cells were xenografted into nude mice and subjected to radiotherapy, micelle treatment or both treatments together. The results showed the tumor volume measurements decreases and calculated survival rate increases, as well as micelles in combination with radiotherapy had significant and superior in vivo antitumor activity compared to single treatment [225].

\section{Other delivery systems}

\subsection{Vaccines}

Use of vaccines to maximize immunogenicity without compromising safety and tolerability has been researched. On the hand, the use of Early 
vaccines often induced long-lived protective immune responses, but tolerability was a major problem. To overcome this problem, the use of NPsbased vaccines in the 1970s, scientists worried about safety, thus using the protein subunits specific for the vaccines responsible for the induction of neutralizing antibodies such as (hemagglutinin from influenza virus), this class of vaccines has a safety profile similar to but does not induce life long, immunity with low immunogenicity. Nanoparticles (NPs) have emerged to solve this safety problem and long immunogenicity, nanoparticle-based vaccines have shown the ability to generate safer vaccines with excellent immunological profile [226-228].

The NPs used in vaccines include virus-like particles (VLPs), and the NPs used to transport vaccines include liposomes, or lipid or polymeric NPs [229]. The use and production of these vaccines can to result in immunogenicity and protection efficacy of polyvalence of surfaces, which are a structural pattern associated with potent geometric pathogens (PASP), and are capables of producing a strong antigen-specific response [226,230,231].

Studies have shown HPV proteins, particularly E6 and E7, integrate DNA viral genes (antigens) into human DNA which are responsible for the development of malignant form and tumor growth, for this reason the development of vaccines against this type of proteins [32]. VPL vaccines were approved for human use, under the trade name Cervarix ${ }^{\circledR}$ and Gardasil ${ }^{\circledR}$, with efficacy by $50 \%$ as preventive vaccines, and they are able to produce antibodies against HPV serotypes types $6,11,16$ and 18 (Gardasil ${ }^{\circledR}$ ) and serotypes types 16 and 18 (Cervarix ${ }^{\circledR}$ ) [3739,232,233].

HPV subtypes (16 and 18) are associated with the development of cervical cancer, with the E6 and E7 oncoproteins, responsible for the disease. A peptide RALA which condenses DNA into cationic nanoparticles (NPs) was loaded into polymeric polyvinylpyrrolidone (PVP) microneedle (MN) patch for cutaneous delivery. RALA condensed E6/E7 DNA into NPs not exceeding $100 \mathrm{~nm}$ in diameter, and afforded the DNA protection from degradation in PVP. In vivo assays showed that the sera from mice vaccinated with patch were richer in E6/E7 specific IgG, exhibited the increase of T cell-mediated cytotoxicity and increase level of interferon gamma (IFN- $\gamma$ ). In this study, it has demonstrated successful cutaneous delivery of a DNA vaccine via in vivo delivery, resulting in a robust antigen-specific immune response [39].

\section{Conclusions}

In summary, there is a great need to find new treatment alternatives for cervical cancer and HPV, which is a major responsible for the cases this cancer. Among the nanocarriers reported in the work are relevant for the treatment of cervical cancer and these nanocarriers show advantages: the increase of drug solubility, minimize the number of doses, provide better stability, control and modulate of drug release, ability to internalize and target to the tumor cell volume-surface ratio becomes susceptible to enzymatic.

The systems cited above have the ability to use for vaccines and they are able to produce a better response.

Nanocarriers-based formulations can offer attractive tool for the use, safety and effective delivery of drug, however, more studies should be performed on animal models, mainly model of cervical cancer, as a pre-clinical stage, in addition to the toxicological studies, for the development and safety of nanocarriers-based medicines.

\section{Acknowledgments}

This work was supported by Conselho Nacional de Pesquisa e Desenvolvimento (CNPq); Fundação de Amparo à Pesquisa do Estado de São Paulo (FAPESP); Coordenação de Aperfeiçoamento de Pessoal de Nível Superior (CAPES) and Programa de Apoio ao Desenvolvimento Científico da Faculdade de Ciências Farmacêuticas da UNESP (PADC) FCF-UNESP).

\section{Conflict of interest statement}

The authors declare the research was conducted in the absence any commercial relationship and there is not potential conflicts of interest.

\section{Authors contributions}

All authors contributed and approved to the final version of the manuscript.

\section{References}

[1] C.I. Ali, N.E. Makata, Cervical cancer: a health limiting condition, Gynecol. Obstet. 6 (2016) 1000378.

[2] H. zur Hausen, Papillomaviruses-to vaccination and beyond, Biochemistry 73 (2008) 498-503.

[3] B.A. Chabner, T.G. Roberts, Chemotherapy and the war on cancer, Nat. Rev. Cancer 5 (2005) 65-72.

[4] T. Iwamoto, Clinical application of drug delivery systems in cancer chemotherapy: review of the efficacy and side effects of approved drugs, Biol. Pharm. Bull. 36 (2013) 715-718.

[5] Q. Hu, W. Sun, C. Wang, Z. Gu, Recent advances of cocktail chemotherapy by combination drug delivery systems, Adv. Drug Deliv. Rev. 98 (2016) 19-34.

[6] M. Hamidi, A. Azadi, P. Rafiei, H. Ashrafi, A Pharmacokinetic Overview of Nanotechnology-Based Drug Delivery Systems: An ADME-Oriented Approach, Vol. 30, 2013 435-467.

[7] J. Vikas, J. Shikha, S.C. Mahajan, Nanomedicines based drug delivery systems for anti-cancer targeting and treatment, Curr. Drug Deliv. 12 (2015) 177-191.

[8] S. Kalepu, V. Nekkanti, Insoluble drug delivery strategies: review of recent advances and business prospects, Acta Pharm. Sin. B 5 (2015) 442-453.

[9] P. van Hoogevest, X. Liu, A. Fahr, Drug delivery strategies for poorly water-soluble drugs: the industrial perspective, Expert Opin. Drug Deliv. 8 (2011) 1481-1500.

[10] A. Fahr, X. Liu, Drug delivery strategies for poorly water-soluble drugs, Expert Opin. Drug Deliv, 4 (2007) 403-416.

[11] Y. Barenholz, Doxilß-the first FDA-approved nano-drug: lessons learned, J. Control. Release 160 (2012) 117-134.

[12] D.W. Northfelt, B.J. Dezube, J.A. Thommes, B.J. Miller, M.A. Fischl, A. Friedman-Kien, L.D. Kaplan, C. Du Mond, R.D. Mamelok, D.H. Henry, Pegylated-liposomal doxorubicin versus doxorubicin, bleomycin, and vincristine in the treatment of AIDS-related Kaposi's sarcoma: results of a randomized phase III clinical trial, J. Clin. Oncol. 16 (1998) 2445-2451.

[13] S. Stewart, H. Jablonowski, F.D. Goebel, K. Arasteh, M. Spittle, A. Rios, D. Aboulafia, J. Galleshaw, B.J. Dezube, Randomized comparative trial of pegylated liposomal doxorubicin versus bleomycin and vincristine in the treatment of AIDS-related Kaposi's sarcoma. International Pegylated liposomal doxorubicin study group, J. Clin. Oncol. 16 (1998) 683-691.

[14] P.S. Gill, J. Wernz, D.T. Scadden, P. Cohen, G.M. Mukwaya, J.H. von Roenn, M. Jacobs, S. Kempin, I. Silverberg, G. Gonzales, M.U. Rarick, A.M. Myers, F. Shepherd, C. Sawka, M.C. Pike, M.E. Ross, Randomized phase III trial of liposomal daunorubicin versus doxorubicin, bleomycin, and vincristine in AIDS-related Kaposi's sarcoma, J. Clin. Oncol. 14 (1996) 2353-2364.

[15] J.W. Hiemenz, T.J. Walsh, Lipid formulations of amphotericin B: recent progress and future directions, Clin. Infect. Dis. 22 (Suppl. 2) (1996) S133-144.

[16] M.J. Glantz, S. LaFollette, K.A. Jaeckle, W. Shapiro, L. Swinnen, J.R. Rozental, S. Phuphanich, L.R. Rogers, J.C. Gutheil, T. Batchelor, D. Lyter, M. Chamberlain, B.L. Maria, C. Schiffer, R. Bashir, D. Thomas, W. Cowens, S.B. Howell, Randomized trial of a slow-release versus a standard formulation of cytarabine for the intrathecal treatment of lymphomatous meningitis, J. Clin. Oncol. 17 (1999) 3110-3116.

[17] W.J. Gradishar, S. Tjulandin, N. Davidson, H. Shaw, N. Desai, P. Bhar, M. Hawkins, J. O'Shaughnessy, Phase III trial of nanoparticle albumin-bound paclitaxel compared with polyethylated castor oil-based paclitaxel in women with breast cancer, J. Clin. Oncol. 23 (2005) 7794-7803.

[18] M.A. Rodriguez, R. Pytlik, T. Kozak, M. Chhanabhai, R. Gascoyne, B. Lu, S.R. Deitcher, J.N. Winter, Vincristine sulfate liposomes injection (Marqibo) in heavily pretreated patients with refractory aggressive non-Hodgkin lymphoma, Cancer 115 (2009) 3475-3482.

[19] G.M. Thomas, Improved treatment for cervical cancer - concurrent chemotherapy and radiotherapy, N. Engl. J. Med. 340 (1999) 1198-1200.

[20] G. Ren, Y.-p. Zhao, L. Yang, C.-X. Fu, Anti-proliferative effect of clitocine from the mushroom Leucopaxillus giganteus on human cervical cancer HeLa cells by inducing apoptosis, Cancer Lett. 262 (2008) 190-200.

[21] G. Alsbeih, HPV infection in cervical and other cancers in Saudi Arabia: implication for prevention and vaccination, Front. Oncol. 4 (2014) 65.

[22] T.A. Kessler, Cervical cancer: prevention and early detection, Semin. Oncol. Nurs. 33 (2017) 172-183.

[23] INCA, Estimativa 2016: incidência de câncer no Brasil, INCA, Rio de Janeiro, 2015.

[24] M. Peiretti, I. Zapardiel, V. Zanagnolo, F. Landoni, C.P. Morrow, A. Maggioni, Management of recurrent cervical cancer: a review of the literature, Surg. Oncol. 21 (2012) e59-e66.

[25] M.A. Clarke, N. Wentzensen, L. Mirabello, A. Ghosh, S. Wacholder, A. Harari, A. Lorincz, M. Schiffman, R.D. Burk, Human papillomavirus DNA methylation as a potential biomarker for cervical cancer, Cancer Epidemiol. Biomarkers Prev. 21 (2012) 2125-2137. 
[26] R. Roden, T.C. Wu, How will HPV vaccines affect cervical cancer? Nat. Rev. Cancer 6 (2006) 753-763.

[27] A. Bansal, M. Singh, B. Rai, Human papillomavirus-associated cancers: a growing global problem, Int. J. Appl. Basic Med. Res. 6 (2016) 84-89.

[28] F.X. Bosch, A. Lorincz, N. Muñoz, C.J.L.M. Meijer, K.V. Shah, The causal relation between human papillomavirus and cervical cancer, J. Clin. Pathol. 55 (2002) 244.

[29] J. Paavonen, Human papillomavirus infection and the development of cervical cancer and related genital neoplasias, Int. J. Infect. Dis. 11 (2007) S3-S9.

[30] E.E. Moore, J.D. Wark, J.L. Hopper, B. Erbas, S.M. Garland, The roles of genetic and environmental factors on risk of cervical cancer: a review of classical twin studies, Twin Res. Hum. Genet. 15 (2012) 79-86.

[31] D.M. Maher, M.C. Bell, E.A. O'Donnell, B.K. Gupta, M. Jaggi, S.C. Chauhan, Curcumin suppresses human papillomavirus oncoproteins, restores $\mathrm{p} 53$, rb, and ptpn13 proteins and inhibits benzo[a]pyrene-induced upregulation of HPV E7, Mol. Carcinog. 50 (2011) 47-57.

[32] S. Alam, M.J. Conway, H.-S. Chen, C. Meyers, The cigarette smoke carcinogen benzo[a]pyrene enhances human papillomavirus synthesis, J. Virol. 82 (2008) 1053-1058.

[33] A.T. Schroen, R.D. Cress, Use of surgical procedures and adjuvant therapy in rectal cancer treatment: a population-based study, Ann. Surg. 234 (2001) 641-651.

[34] P. Therasse, S.G. Arbuck, E.A. Eisenhauer, J. Wanders, R.S. Kaplan, L. Rubinstein, J. Verweij, M. Van Glabbeke, A.T. van Oosterom, M.C. Christian, S.G. Gwyther, New guidelines to evaluate the response to treatment in solid tumors. European Organization for Research and Treatment of cancer, National Cancer Institute of the United States, National Cancer Institute of Canada, J. Natl. Cancer Inst. 92 (2000) 205-216.

[35] A. Sudhakar, History of cancer, ancient and modern treatment methods, J. Cancer Sci. Ther. 1 (2009) 1-4.

[36] R. Baskar, K.A. Lee, R. Yeol, K.-W. Yeoh, Cancer and radiation therapy: current advances and future directions, Int. J. Med. Sci. 9 (2012) 193-199.

[37] K. Kwak, A. Yemelyanova, R.B.S. Roden, Prevention of cancer by prophylactic human papillomavirus vaccines, Curr. Opin. Immunol. 23 (2011) 244-251.

[38] J.G. Dauner, Y. Pan, A. Hildesheim, C. Harro, L.A. Pinto, Characterization of the HPVspecific memory B cell and systemic antibody responses in women receiving an unadjuvanted HPV16 L1 VLP vaccine, Vaccine 28 (2010) 5407-5413.

[39] A.A. Ali, C.M. McCrudden, J. McCaffrey, J.W. McBride, G. Cole, N.J. Dunne, T. Robson, A. Kissenpfennig, R.F. Donnelly, H.O. McCarthy, DNA vaccination for cervical cancer; a novel technology platform of RALA mediated gene delivery via polymeric microneedles, Nanomedicine 13 (2017) 921-932.

[40] J.L. Vivero-Escoto, I.I. Slowing, V.S.Y. Lin, Tuning the cellular uptake and cytotoxicity properties of oligonucleotide intercalator-functionalized mesoporous silica nanoparticles with human cervical cancer cells HeLa, Biomaterials 31 (2010) 1325-1333.

[41] Y. Zheng, H. Chen, X. Zeng, Z. Liu, X. Xiao, Y. Zhu, D. Gu, L. Mei, Surface modification of TPGS-b-(PCL-ran-PGA) nanoparticles with polyethyleneimine as a co-delivery system of TRAIL and endostatin for cervical cancer gene therapy, Nanoscale Res. Lett. 8 (2013) 161

[42] X. Zeng, W. Tao, L. Mei, L. Huang, C. Tan, S.-S. Feng, Cholic acid-functionalized nanoparticles of star-shaped PLGA-vitamin E TPGS copolymer for docetaxel delivery to cervical cancer, Biomaterials 34 (2013) 6058-6067.

[43] S.M. Dizaj, F. Lotfipour, M. Barzegar-Jalali, M.H. Zarrintan, K. Adibkia, Antimicrobial activity of the metals and metal oxide nanoparticles, Mater. Sci. Eng. C 44 (2014) 278-284.

[44] G.P. Kumar, P. Rajeshwarrao, Nonionic surfactant vesicular systems for effective drug delivery-an overview, Acta Pharm. Sin. B 1 (2011) 208-219.

[45] B. Fonseca-Santos, M. Chorilli, An overview of carboxymethyl derivatives of chitosan: their use as biomaterials and drug delivery systems, Mater. Sci. Eng. C 77 (2017) 1349-1362.

[46] B. Fonseca-Santos, M.P.D. Gremião, M. Chorilli, Nanotechnology-based drug delivery systems for the treatment of Alzheimer's disease, Int. J. Nanomedicine 10 (2015) 4981-5003.

[47] Y.N. Dou, J. Zheng, W.D. Foltz, R. Weersink, N. Chaudary, D.A. Jaffray, C. Allen, Heatactivated thermosensitive liposomal cisplatin (HTLC) results in effective growth delay of cervical carcinoma in mice, J. Control. Release 178 (2014) 69-78.

[48] F. Wang, L. Li, B. Liu, Z. Chen, C. Li, Hyaluronic acid decorated pluronic P85 solid lipid nanoparticles as a potential carrier to overcome multidrug resistance in cervical and breast cancer, Biomed Pharmacother 86 (2017) 595-604.

[49] T. Boulikas, G.P. Staphopoulos, N. Volakakis, M. Vougiouka, Systemic lipoplatin infusion results in preferential tumor uptake in human studies, Anticancer Res. 25 (2005) 3031-3039.

[50] A.Z. Wang, R. Langer, O.C. Farokhzad, Nanoparticle delivery of cancer drugs, Annu. Rev. Med. 63 (2012) 185-198.

[51] J.W. Nichols, Y.H. Bae, EPR: evidence and fallacy, J. Control. Release 190 (2014) 451-464.

[52] F. Danhier, To exploit the tumor microenvironment: since the EPR effect fails in the clinic, what is the future of nanomedicine? J. Control. Release 244 (2016) 108-121.

[53] H. Maeda, The enhanced permeability and retention (EPR) effect in tumor vasculature: the key role of tumor-selective macromolecular drug targeting, Adv. Enzym. Regul. 41 (2001) 189-207.

[54] H. Maeda, J. Wu, T. Sawa, Y. Matsumura, K. Hori, Tumor vascular permeability and the EPR effect in macromolecular therapeutics: a review, J. Control. Release 65 (2000) 271-284.

[55] V. Torchilin, Tumor delivery of macromolecular drugs based on the EPR effect, Adv. Drug Deliv. Rev. 63 (2011) 131-135.

[56] J. Fang, H. Nakamura, H. Maeda, The EPR effect: unique features of tumor blood vessels for drug delivery, factors involved, and limitations and augmentation of the effect, Adv. Drug Deliv. Rev. 63 (2011) 136-151.
[57] H. Maeda, Toward a full understanding of the EPR effect in primary and metastatic tumors as well as issues related to its heterogeneity, Adv. Drug Deliv. Rev. 91 (2015) 3-6.

[58] H. Kobayashi, R. Watanabe, P.L. Choyke, Improving conventional enhanced permeability and retention (EPR) effects; what is the appropriate target? Theranostics 4 (2014) 81-89.

[59] H. Maeda, Macromolecular therapeutics in cancer treatment: the EPR effect and beyond, J. Control. Release 164 (2012) 138-144.

[60] A. Schroeder, D.A. Heller, M.M. Winslow, J.E. Dahlman, G.W. Pratt, R. Langer, T. Jacks, D.G. Anderson, Treating metastatic cancer with nanotechnology, Nat. Rev. Cancer 12 (2012) 39-50.

[61] A. Yaghmur, O. Glatter, Characterization and potential applications of nanostructured aqueous dispersions, Adv. Colloid Interf. Sci. 147 (2009) 333-342.

[62] S. Khan, S. Baboota, J. Ali, S. Khan, R.S. Narang, J.K. Narang, Nanostructured lipid carriers: an emerging platform for improving oral bioavailability of lipophilic drugs, Int. J. Pharm. Investig. 5 (2015) 182-191.

[63] S.V. Talluri, G. Kuppusamy, V.V.S.R. Karri, S. Tummala, S.V. Madhunapantula, Lipidbased nanocarriers for breast cancer treatment - comprehensive review, Drug Deliv. 23 (2016) 1291-1305.

[64] R.H. Müller, K. Mäder, S. Gohla, Solid lipid nanoparticles (SLN) for controlled drug delivery - a review of the state of the art, Eur. J. Pharm. Biopharm. 50 (2000) 161-177.

[65] A.R. Voltan, G. Quindós, K.P.M. Alarcón, A.M. Fusco-Almeida, M.J.S. MendesGiannini, M. Chorilli, Fungal diseases: could nanostructured drug delivery systems be a novel paradigm for therapy? Int. J. Nanomedicine 11 (2016) 3715-3730.

[66] R.H. Müller, M. Radtke, S.A. Wissing, Solid lipid nanoparticles (SLN) and nanostruc tured lipid carriers (NLC) in cosmetic and dermatological preparations, Adv. Drug Deliv. Rev. 54 (2002) S131-S155.

[67] A. Rupenagunta, I. Somasundaram, J. Kausalya, B. Senthilnathan, Solid Lipid Nanoparticles-A Versatile Carrier System, 2011.

[68] J.-S. Baek, C.-W. Cho, Controlled release and reversal of multidrug resistance by coencapsulation of paclitaxel and verapamil in solid lipid nanoparticles, Int. J. Pharm. 478 (2015) 617-624.

[69] V. Jannin, J. Musakhanian, D. Marchaud, Approaches for the development of solid and semi-solid lipid-based formulations, Adv. Drug Deliv. Rev. 60 (2008) 734-746.

[70] V. Jenning, A.F. Thünemann, S.H. Gohla, Characterisation of a novel solid lipid nanoparticle carrier system based on binary mixtures of liquid and solid lipids, Int. J. Pharm. 199 (2000) 167-177.

[71] M. Rizwanullah, J. Ahmad, S. Amin, Nanostructured lipid carriers: a novel platform for chemotherapeutics, Curr. Drug Deliv. 13 (2016) 4-26.

[72] T.H. Tran, J.Y. Choi, T. Ramasamy, D.H. Truong, C.N. Nguyen, H.-G. Choi, C.S. Yong, J.O. Kim, Hyaluronic acid-coated solid lipid nanoparticles for targeted delivery of vorinostat to CD44 overexpressing cancer cells, Carbohydr. Polym. 114 (2014) 407-415.

[73] A.J. Almeida, E. Souto, Solid lipid nanoparticles as a drug delivery system for peptides and proteins, Adv. Drug Deliv. Rev. 59 (2007) 478-490.

[74] C. Schwarz, W. Mehnert, J.S. Lucks, R.H. Müller, Solid lipid nanoparticles (SLN) for controlled drug delivery. I. Production, characterization and sterilization, J. Control. Release 30 (1994) 83-96.

[75] M.N. Uddin, S.A. Kouzi, M.D. Hussain, Strategies for developing oral vaccines for human papillomavirus (HPV) induced cancer using nanoparticle mediated delivery system, J. Pharm. Pharm. Sci. 18 (2015) 220-234.

[76] X. Xu, W. Ho, X. Zhang, N. Bertrand, O. Farokhzad, Cancer nanomedicine: from targeted delivery to combination therapy, Trends Mol. Med. 21 (2015) 223-232.

[77] J. Huo, S.-w. Zhou, New research on development of solid lipid nanoparticles, J. Med. Coll. PLA 22 (2007) 385-390.

[78] D. Liu, Z. Liu, L. Wang, C. Zhang, N. Zhang, Nanostructured lipid carriers as novel carrier for parenteral delivery of docetaxel, Colloids Surf. B: Biointerfaces 85 (2011) 262-269.

[79] B. Liu, L. Han, J. Liu, S. Han, Z. Chen, L. Jiang, Co-delivery of paclitaxel and TOS-cisplatin via TAT-targeted solid lipid nanoparticles with synergistic antitumor activity against cervical cancer, Int. J. Nanomedicine 12 (2017) 955-968.

[80] M.A. Jordan, L. Wilson, Microtubules as a target for anticancer drugs, Nat. Rev. Cancer 4 (2004) 253-265.

[81] P. Ma, R.J. Mumper, Paclitaxel nano-delivery systems: a comprehensive review, J. Nanomed. Nanotechnol. 4 (2013) 1000164.

[82] Z.-J. Chen, Z. Zhang, B.-B. Xie, H.-Y. Zhang, Development and evaluation of topotecan loaded solid lipid nanoparticles: a study in cervical cancer cell lines, J. Photochem. Photobiol. B Biol. 165 (2016) 182-188.

[83] A.C. Silva, D. Santos, D. Ferreira, C.M. Lopes, Lipid-based nanocarriers as an alternative for oral delivery of poorly water-soluble drugs: peroral and mucosal routes, Curr. Med. Chem. 19 (2012) 4495-4510.

[84] A.L.R. Souza, C.P. Kiill, F.K.D. Santos, G.M.D. Luz, H. Rocha-e-Silva, M. Chorilli, M.P.D Gremião, Nanotechnology-based drug delivery systems for dermatomycosis treatment, Curr. Nanosci. 8 (2012) 512-519.

[85] P. Couvreur, E. Fattal, A. Andremont, Liposomes and nanoparticles in the treatment of intracellular bacterial infections, Pharm. Res. 8 (1991) 1079-1086.

[86] W. Jiskoot, T. Teerlink, E.C. Beuvery, D.J. Crommelin, Preparation of liposomes via detergent removal from mixed micelles by dilution. The effect of bilayer composition and process parameters on liposome characteristics, Pharm. Weekbl. 8 (1986) 259-265 (Scientific edition).

[87] D.W. Deamer, Preparation and properties of ether-injection liposomes *, Ann. N. Y. Acad. Sci. 308 (1978) 250-258.

[88] F. Szoka, D. Papahadjopoulos, Procedure for preparation of liposomes with large internal aqueous space and high capture by reverse-phase evaporation, Proc. Natl. Acad. Sci. 75 (1978) 4194-4198. 
[89] A.A. Attama, V.E. Mpamaugo, Pharmacodynamics of piroxicam from self-emulsifying lipospheres formulated with homolipids extracted from Capra hircus, Drug Deliv. 13 (2006) 133-137.

[90] L.A. Meure, N.R. Foster, F. Dehghani, Conventional and dense gas techniques for the production of liposomes: a review, AAPS PharmSciTech 9 (2008) 798

[91] U. Sankar Kadimi, D.R. Balasubramanian, U.R. Ganni, M. Balaraman, V. Govindarajulu, In vitro studies on liposomal amphotericin B obtained by supercritical carbon dioxide-mediated process, Nanomedicine 3 (2007) 273-280.

[92] F. Frézard, D.A. Schettini, O.G.F. Rocha, C. Demicheli, Lipossomas: propriedades físico-químicas e farmacológicas, aplicações na quimioterapia à base de antimônio, Quím. Nova 28 (2005) 511-518.

[93] T.L. Andresen, S.S. Jensen, K. Jørgensen, Advanced strategies in liposomal cance therapy: problems and prospects of active and tumor specific drug release, Prog. Lipid Res. 44 (2005) 68-97.

[94] J.O. Eloy, M. Claro de Souza, R. Petrilli, J.P.A. Barcellos, R.J. Lee, J.M. Marchetti, Liposomes as carriers of hydrophilic small molecule drugs: strategies to enhance encapsulation and delivery, Colloids Surf. B: Biointerfaces 123 (2014) 345-363.

[95] A. Sosnik, J. das Neves, B. Sarmento, Mucoadhesive polymers in the design of nanodrug delivery systems for administration by non-parenteral routes: a review, Prog. Polym. Sci. 39 (2014) 2030-2075.

[96] T. Lian, R.J.Y. Ho, Trends and developments in liposome drug delivery systems, J Pharm. Sci. 90 (2001) 667-680.

[97] M. Amidi, E. Mastrobattista, W. Jiskoot, W.E. Hennink, Chitosan-based delivery systems for protein therapeutics and antigens, Adv. Drug Deliv. Rev. 62 (2010) 59-82.

[98] P.R. Karn, Z. Vanić, I. Pepić, N. Škalko-Basnet, Mucoadhesive liposomal delivery systems: the choice of coating material, Drug Dev. Ind. Pharm. 37 (2011) 482-488.

[99] S. Zong, X. Wang, Y. Yang, W. Wu, H. Li, Y. Ma, W. Lin, T. Sun, Y. Huang, Z. Xie, Y. Yue S. Liu, X. Jing, The use of cisplatin-loaded mucoadhesive nanofibers for local chemotherapy of cervical cancers in mice, Eur. J. Pharm. Biopharm. 93 (2015) 127-135.

[100] S. Saesoo, S. Bunthot, W. Sajomsang, P. Gonil, S. Phunpee, P. Songkhum, K. Laohhasurayotin, T. Wutikhun, T. Yata, U.R. Ruktanonchai, N. Saengkrit, Phospholipid-chitosan hybrid nanoliposomes promoting cell entry for drug delivery against cervical cancer, J. Colloid Interface Sci. 480 (2016) 240-248.

[101] M.-X. Chen, B.-K. Li, D.-K. Yin, J. Liang, S.-S. Li, D.-Y. Peng, Layer-by-layer assembly of chitosan stabilized multilayered liposomes for paclitaxel delivery, Carbohydr Polym. 111 (2014) 298-304.

[102] H. Mizutani, S. Tada-Oikawa, Y. Hiraku, M. Kojima, S. Kawanishi, Mechanism of apoptosis induced by doxorubicin through the generation of hydrogen peroxide, Life Sci. 76 (2005) 1439-1453.

[103] D. Bellarosa, A. Ciucci, A. Bullo, F. Nardelli, S. Manzini, C.A. Maggi, C. Goso, Apoptotic events in a human ovarian cancer cell line exposed to anthracyclines, J. Pharmacol. Exp. Ther. 296 (2001) 276-283.

104] S.K. Sriraman, G. Salzano, C. Sarisozen, V. Torchilin, Anti-cancer activity of doxorubicin-loaded liposomes co-modified with transferrin and folic acid, Eur. J. Pharm. Biopharm. 105 (2016) 40-49.

[105] K. Lappalainen, L. Pirila, I. Jaaskelainen, K. Syrjanen, S. Syrjanen, Effects of liposoma antisense oligonucleotides on mRNA and protein levels of the HPV 16 E7 oncogene, Anticancer Res. 16 (1996) 2485-2492.

[106] Z. Cui, S.-J. Han, L. Huang, Coating of mannan on LPD particles containing HPV E7 peptide significantly enhances immunity against HPV-positive tumor, Pharm. Res. 21 (2004) 1018-1025.

[107] M. Jiang, C.P. Rubbi, J. Milner, Gel-based application of siRNA to human epithelial cancer cells induces RNAi-dependent apoptosis, Oligonucleotides 14 (2004) 239-248.

[108] Z. Cui, L. Huang, Liposome-polycation-DNA (LPD) particle as a carrier and adjuvant for protein-based vaccines: therapeutic effect against cervical cancer, Cancer Immunol. Immunother. 54 (2005) 1180-1190.

[109] X.Y. Niu, Z.L. Peng, W.Q. Duan, H. Wang, P. Wang, Inhibition of HPV 16 E6 oncogene expression by RNA interference in vitro and in vivo, Int. J. Gynecol. Cancer 16 (2006) 743-751.

[110] W. Chen, W. Yan, L. Huang, A simple but effective cancer vaccine consisting of an antigen and a cationic lipid, Cancer Immunol. Immunother. 57 (2008) 517-530.

[111] X.Z. Chen, K.J. Zhu, Y. Xu, X.Y. Tang, X.Z. Cai, X. Zhang, H. Cheng, RNA interference silences the human papillomavirus 6b/11 early gene E7 in vitro and in vivo, Clin. Exp. Dermatol. 35 (2010) 509-515.

[112] M. Foldvari, I. Badea, P. Kumar, S. Wettig, R. Batta, M.J. King, Z. He, E. Yeboah, K. Gaspar, P. Hull, N.H. Shear, Biphasic vesicles for topical delivery of interferon alpha in human volunteers and treatment of patients with human papillomavirus infections, Curr. Drug Deliv. 8 (2011) 307-319.

[113] M. Mizuuchi, Y. Hirohashi, T. Torigoe, T. Kuroda, K. Yasuda, Y. Shimizu, T. Saito N. Sato, Novel oligomannose liposome-DNA complex DNA vaccination efficiently evokes anti-HPV E6 and E7 CTL responses, Exp. Mol. Pathol. 92 (2012) 185-190.

[114] J.-g. Li, L. Li, S.-w. Zhang, X. Wei, HPV16E7-specific siRNA inhibits cell proliferation in CaSki cells, Cell Biochem. Biophys. 71 (2015) 529-534.

[115] A. Lechanteur, T. Furst, B. Evrard, P. Delvenne, P. Hubert, G. Piel, Development of anti-E6 pegylated lipoplexes for mucosal application in the context of cervical preneoplastic lesions, Int. J. Pharm. 483 (2015) 268-277.

[116] H. Chapoy-Villanueva, I. Martinez-Carlin, G. Lopez-Berestein, A. Chavez-Reyes, Therapeutic silencing of HPV 16 E7 by systemic administration of siRNA-neutra DOPC nanoliposome in a murine cervical cancer model with obesity, J. of B.U.ON 20 (2015) 1471-1479.

[117] P.M. Daftarian, M. Mansour, B. Pohajdak, A. Fuentes-Ortega, E. Korets-Smith, L. MacDonald, G. Weir, R.G. Brown, W.M. Kast, Rejection of large HPV-16 expressing tumors in aged mice by a single immunization of VacciMax ${ }^{\circledR}$ encapsulated CTL/T helper peptides, J. Transl. Med. 5 (2007) 26.
[118] K. Münger, P.M. Howley, Human papillomavirus immortalization and transformation functions, Virus Res. 89 (2002) 213-228.

[119] M.L. Hauck, S.M. LaRue, W.P. Petros, J.M. Poulson, D. Yu, I. Spasojevic, A.F. Pruitt, A. Klein, B. Case, D.E. Thrall, D. Needham, M.W. Dewhirst, Phase I trial of doxorubicincontaining low temperature sensitive liposomes in spontaneous canine tumors, Clin. Cancer Res. 12 (2006) 4004-4010.

[120] P.S. Yarmolenko, Y. Zhao, C. Landon, I. Spasojevic, F.A.N. Yuan, D. Needham, B.L. Viglianti, M.W. Dewhirst, Comparative effects of thermosensitive doxorubicin-containing liposomes and hyperthermia in human and murine tumours, Int. J. Hyperth. 26 (2010) 485-498.

[121] L. Li, T.L.M. ten Hagen, M. Hossann, R. Süss, G.C. van Rhoon, A.M.M. Eggermont, D. Haemmerich, G.A. Koning, Mild hyperthermia triggered doxorubicin release from optimized stealth thermosensitive liposomes improves intratumoral drug delivery and efficacy, J. Control. Release 168 (2013) 142-150.

[122] S.M.Z.M.D. Ferreira, G.P. Domingos, D.D.S. Ferreira, T.G.R. Rocha, R. Serakides, C.M. de Faria Rezende, V.N. Cardoso, S.O.A. Fernandes, M.C. Oliveira, Technetium-99mlabeled ceftizoxime loaded long-circulating and $\mathrm{pH}$-sensitive liposomes used to identify osteomyelitis, Bioorg. Med. Chem. Lett. 22 (2012) 4605-4608.

[123] M.J. Morilla, J. Montanari, F. Frank, E. Malchiodi, R. Corral, P. Petray, E.L. Romero, Etanidazole in pH-sensitive liposomes: design, characterization and in vitro/in vivo anti-Trypanosoma cruzi activity, J. Control. Release 103 (2005) 599-607.

[124] E. Torres, F. Mainini, R. Napolitano, F. Fedeli, R. Cavalli, S. Aime, E. Terreno, Improved paramagnetic liposomes for MRI visualization of $\mathrm{pH}$ triggered release, J. Control. Release 154 (2011) 196-202.

[125] N. Saengkrit, S. Saesoo, W. Srinuanchai, S. Phunpee, U.R. Ruktanonchai, Influence of curcumin-loaded cationic liposome on anticancer activity for cervical cancer therapy, Colloids Surf. B: Biointerfaces 114 (2014) 349-356.

[126] J.G. Fewell, M. Matar, G. Slobodkin, S.-O. Han, J. Rice, B. Hovanes, D.H. Lewis, K. Anwer, Synthesis and application of a non-viral gene delivery system for immunogene therapy of cancer, J. Control. Release 109 (2005) 288-298.

[127] S. Strieth, C.F. Nussbaum, M.E. Eichhorn, M. Fuhrmann, M. Teifel, U. Michaelis, A Berghaus, M. Dellian, Tumor-selective vessel occlusions by platelets after vascular targeting chemotherapy using paclitaxel encapsulated in cationic liposomes, Int. J. Cancer 122 (2008) 452-460.

[128] S. Shafiq, F. Shakeel, S. Talegaonkar, F.J. Ahmad, R.K. Khar, M. Ali, Development and bioavailability assessment of ramipril nanoemulsion formulation, Eur. J. Pharm. Biopharm. 66 (2007) 227-243.

[129] K. Hippalgaonkar, S. Majumdar, V. Kansara, Injectable lipid emulsions-advancements, opportunities and challenges, AAPS PharmSciTech 11 (2010) 1526-1540

[130] S. Ganta, M. Talekar, A. Singh, T.P. Coleman, M.M. Amiji, Nanoemulsions in translational research-opportunities and challenges in targeted cancer therapy, AAPS PharmSciTech 15 (2014) 694-708

[131] W.P. Caron, J.C. Lay, A.M. Fong, N.M. La-Beck, P. Kumar, S.E. Newman, H. Zhou, J.H. Monaco, D.L. Clarke-Pearson, W.R. Brewster, L. Van Le, V.L. Bae-Jump, P.A. Gehrig, W.C. Zamboni, Translational studies of phenotypic probes for the mononuclear phagocyte system and liposomal pharmacology, J. Pharmacol. Exp. Ther. 347 (2013) 599-606.

[132] B.K. Kang, S.K. Chon, S.H. Kim, S.Y. Jeong, M.S. Kim, S.H. Cho, H.B. Lee, G. Khang, Controlled release of paclitaxel from microemulsion containing PLGA and evaluation of anti-tumor activity in vitro and in vivo, Int. J. Pharm. 286 (2004) 147-156.

[133] P. Rajpoot, V. Bali, K. Pathak, Anticancer efficacy, tissue distribution and blood pharmacokinetics of surface modified nanocarrier containing melphalan, Int. J. Pharm. 426 (2012) 219-230.

[134] J.-B. Tagne, S. Kakumanu, D. Ortiz, T. Shea, R.J. Nicolosi, A Nanoemulsion formulation of tamoxifen increases its efficacy in a breast cancer cell line, Mol. Pharm. 5 (2008) 280-286

[135] N.T. Huynh, C. Passirani, P. Saulnier, J.P. Benoit, Lipid nanocapsules: a new platform for nanomedicine, Int. J. Pharm. 379 (2009) 201-209.

[136] T.M. Allen, P.R. Cullis, Drug delivery systems: entering the mainstream, Science 303 (2004) 1818-1822.

[137] D. Hoarau, P. Delmas, S.X.E. David, E. Roux Phanie, J.-C. Leroux, Novel long-circulating lipid nanocapsules, Pharm. Res. 21 (2004) 1783-1789.

[138] M.N. Khalid, P. Simard, D. Hoarau, A. Dragomir, J.-C. Leroux, Long circulating poly(ethylene glycol)-decorated lipid nanocapsules deliver docetaxel to solid tumors, Pharm. Res. 23 (2006) 752-758.

[139] K. Brightman, G. Finlay, I. Jarvis, T. Knowlton, C.T. Manktelow, A stability-indicating method for the determination of melphalan and related impurity content by gradient HPLC, J. Pharm. Biomed. Anal. 20 (1999) 439-447.

[140] S. Ganta, A. Singh, P. Kulkarni, A.W. Keeler, A. Piroyan, R. R. Sawant, N. R. Patel, B. Davis, C. Ferris, S. O'Neal, W. Zamboni, M.M. Amiji, T.P. Coleman, EGFR targeted theranostic nanoemulsion for image-guided ovarian cancer therapy, Pharm. Res. 32 (2015) 2753-2763.

[141] A.Z. Wilczewska, K. Niemirowicz, K.H. Markiewicz, H. Car, Nanoparticles as drug delivery systems, Pharmacol. Rep. 64 (2012) 1020-1037.

[142] S. Ranghar, P. Sirohi, P. Verma, V. Agarwal, Nanoparticle-based drug delivery systems: promising approaches against infections, Braz. Arch. Biol. Technol. 57 (2014) 209-222.

[143] P. Couvreur, Nanoparticles in drug delivery: past, present and future, Adv. Drug Deliv. Rev. 65 (2013) 21-23.

[144] E.M. Pridgen, F. Alexis, O.C. Farokhzad, Polymeric nanoparticle technologies for oral drug delivery, Clin. Gastroenterol. Hepatol. 12 (2014) 1605-1610.

[145] Y. Yuan, B. Liu, Self-assembled nanoparticles based on PEGylated conjugated polyelectrolyte and drug molecules for image-guided drug delivery and photodynamic therapy, ACS Appl. Mater. Interfaces 6 (2014) 14903-14910. 
[146] E. Turos, J.-Y. Shim, Y. Wang, K. Greenhalgh, G.S.K. Reddy, S. Dickey, D.V. Lim, Antibiotic-conjugated polyacrylate nanoparticles: new opportunities for development of anti-MRSA agents, Bioorg. Med. Chem. Lett. 17 (2007) 53-56.

[147] G.K. Saraogi, P. Gupta, U.D. Gupta, N.K. Jain, G.P. Agrawal, Gelatin nanocarriers as potential vectors for effective management of tuberculosis, Int. J. Pharm. 385 (2010) 143-149.

[148] M.D.S. Barbi, F.C. Carvalho, C.P. Kiill, H. Da Silva Barud, S.H. Santagneli, S.J.L. Ribeiro, M.P.D. Gremião, Preparation and characterization of chitosan nanoparticles for zidovudine nasal delivery, J. Nanosci. Nanotechnol. 15 (2015) 865-874.

[149] F. Rancan, D. Papakostas, S. Hadam, S. Hackbarth, T. Delair, C. Primard, B. Verrier, W. Sterry, U. Blume-Peytavi, A. Vogt, Investigation of polylactic acid (PLA) nanoparticles as drug delivery systems for local dermatotherapy, Pharm. Res. 26 (2009) 2027-2036.

[150] S.L. Banerjee, M. Khamrai, K. Sarkar, N.K. Singha, P.P. Kundu, Modified chitosan encapsulated core-shell Ag Nps for superior antimicrobial and anticancer activity, Int. J. Biol. Macromol. 85 (2016) 157-167.

[151] R.R. Arvizo, S. Bhattacharyya, R. Kudgus, K. Giri, R. Bhattacharya, P. Mukherjee, Intrinsic therapeutic applications of noble metal nanoparticles: past, present and future, Chem. Soc. Rev. 41 (2012) 2943-2970.

[152] T.A. El-Brolossy, T. Abdallah, M.B. Mohamed, S. Abdallah, K. Easawi, S. Negm, H. Talaat, Shape and size dependence of the surface plasmon resonance of gold nanoparticles studied by photoacoustic technique, Eur. Phys. J. Spec. Top. 153 (2008) 361-364.

[153] M. Eghtedari, A.V. Liopo, J.A. Copland, A.A. Oraevsky, M. Motamedi, Engineering of hetero-functional gold nanorods for the in vivo molecular targeting of breast cancer cells, Nano Lett. 9 (2009) 287-291.

[154] A.A. Alshatwi, J. Athinarayanan, V.S. Periasamy, Green synthesis of bimetallic Au@ Pt nanostructures and their application for proliferation inhibition and apoptosis induction in human cervical cancer cell, J. Mater. Sci. Mater. Med. 26 (2015) 148.

[155] J. Du, H. Singh, T.-H. Yi, Antibacterial, anti-biofilm and anticancer potentials of green synthesized silver nanoparticles using benzoin gum (Styrax benzoin) extract, Bioprocess Biosyst. Eng. 39 (2016) 1923-1931.

[156] B. Duncan, C. Kim, V.M. Rotello, Gold nanoparticle platforms as drug and biomacromolecule delivery systems, J. Control. Release 148 (2010) 122-127.

[157] S. Rana, A. Bajaj, R. Mout, V.M. Rotello, Monolayer coated gold nanoparticles for delivery applications, Adv. Drug Deliv. Rev. 64 (2012) 200-216.

[158] M.F. Tang, L. Lei, S.R. Guo, W.L. Huang, Recent progress in nanotechnology for cancer therapy, Chin. J. Cancer 29 (2010) 775-780.

[159] G. Tomoaia, O. Horovitz, A. Mocanu, A. Nita, A. Avram, C.P. Racz, O. Soritau, M. Cenariu, M. Tomoaia-Cotisel, Effects of doxorubicin mediated by gold nanoparticles and resveratrol in two human cervical tumor cell lines, Colloids Surf. B: Biointerfaces 135 (2015) 726-734.

[160] B.W. Cunningham, C.M. Orbegoso, A.E. Dmitriev, N.J. Hallab, J.C. Sefter, P.C. McAfee, The effect of titanium particulate on development and maintenance of a posterolateral spinal arthrodesis: an in vivo rabbit model, Spine 27 (2002) 1971-1981.

[161] D. Chowdhury, A. Paul, A. Chattopadhyay, Photocatalytic polypyrrole $-\mathrm{TiO}_{2}-$ nanoparticles composite thin film generated at the air - water Interface, Langmuir 21 (2005) 4123-4128.

[162] R.J. Miller, S. Bennett, A.A. Keller, S. Pease, H.S. Lenihan, $\mathrm{TiO}_{2}$ nanoparticles are phototoxic to marine phytoplankton, PLoS One 7 (2012), e30321.

[163] J.C. Reed, Apoptosis-regulating proteins as targets for drug discovery, Trends Mol. Med. 7 (2001) 314-319.

[164] M. Pandurangan, G. Enkhtaivan, J.A. Young, H.J. Hoon, H. Lee, S. Lee, D.H. Kim, In vitro therapeutic potential of $\mathrm{TiO}_{2}$ nanoparticles against human cervical carcinoma cells, Biol. Trace Elem. Res. 171 (2016) 293-300.

[165] N.M. Jukapli, S. Bagheri, Recent developments on titania nanoparticle as photocatalytic cancer cells treatment, J. Photochem. Photobiol. B Biol. 163 (2016) 421-430.

[166] D. Rehana, D. Mahendiran, R.S. Kumar, A.K. Rahiman, Evaluation of antioxidant and anticancer activity of copper oxide nanoparticles synthesized using medicinally important plant extracts, Biomed Pharmacother 89 (2017) 1067-1077.

[167] S. Hackenberg, A. Scherzed, W. Harnisch, K. Froelich, C. Ginzkey, C. Koehler, R. Hagen, N. Kleinsasser, Antitumor activity of photo-stimulated zinc oxide nanoparticles combined with paclitaxel or cisplatin in HNSCC cell lines, J. Photochem. Photobiol. B Biol. 114 (2012) 87-93.

[168] S.-H. Yu, H. Cölfen, A.-W. Xu, W. Dong, Complex spherical BaCO3 superstructures self-assembled by a facile mineralization process under control of simple polyelectrolytes, Cryst. Growth Des. 4 (2004) 33-37.

[169] X.-H. Guo, F. Meng, X. Qu, M. Wang, C. Mao, J. Zhang, W. Wang, S.-H. Yu, Mineralization of unique barium carbonate crystal superstructures controlled by a liquid crystalline phase polymer, CrystEngComm 14 (2012) 3213-3219.

[170] W. Zhu, C. Cai, J. Lin, L. Wang, L. Chen, Z. Zhuang, Polymer micelle-directed growth of $\mathrm{BaCO}_{3}$ spiral nanobelts, Chem. Commun. 48 (2012) 8544-8546.

[171] J. Zhang, C.Q. Lan, M. Post, B. Simard, Y. Deslandes, T.H. Hsieh, Design of Nanoparticles as drug carriers for cancer therapy, Cancer Genomics Proteomics 3 (2006) 147-157.

[172] Y.-N. Wu, D.-H. Chen, X.-Y. Shi, C.-C. Lian, T.-Y. Wang, C.-S. Yeh, K.R. Ratinac, P. Thordarson, F. Braet, D.-B. Shieh, Cancer-cell-specific cytotoxicity of non-oxidized iron elements in iron core-gold shell NPs, Nanomedicine 7 (2011) 420-427.

[173] I. Lynch, K.A. Dawson, S. Linse, Detecting cryptic epitopes created by nanoparticles, Sci. STKE 2006 (2006) pe14.

[174] P.C. Nagajyothi, M. Pandurangan, T.V.M. Sreekanth, J. Shim, In vitro anticancer potential of $\mathrm{BaCO}_{3}$ nanoparticles synthesized via green route, J. Photochem. Photobiol. B Biol. 156 (2016) 29-34.

[175] D.A. Tomalia, Birth of a new macromolecular architecture: dendrimers as quantized building blocks for nanoscale synthetic polymer chemistry, Prog. Polym. Sci. 30 (2005) 294-324.
[176] D.A. Tomalia, H. Baker, J. Dewald, M. Hall, G. Kallos, S. Martin, J. Roeck, J. Ryder, P. Smith, A new class of polymers: starburst-dendritic macromolecules, Polym. J. 17 (1985) 117-132.

[177] S.M. Grayson, J.M.J. Fréchet, Convergent dendrons and dendrimers: from synthesis to applications, Chem. Rev. 101 (2001) 3819-3868.

[178] J.F.G.A. Jansen, E.M.M. de Brabander-van den Berg, E.W. Meijer, Encapsulation of guest molecules into a dendritic box, Science 266 (1994) 1226-1229.

[179] R.W.J. Scott, O.M. Wilson, R.M. Crooks, Synthesis, characterization, and applications of dendrimer-encapsulated nanoparticles, J. Phys. Chem. B 109 (2005) 692-704.

[180] K. Aoi, K. Itoh, M. Okada, Globular carbohydrate macromolecules "sugar balls". 1. Synthesis of novel sugar-persubstituted poly(amido amine) dendrimers, Macromolecules 28 (1995) 5391-5393.

[181] S. Zhu, M. Hong, L. Zhang, G. Tang, Y. Jiang, Y. Pei, PEGylated PAMAM dendrimerdoxorubicin conjugates: in vitro evaluation and in vivo tumor accumulation, Pharm. Res. 27 (2010) 161-174.

[182] B.M. Rosen, C.J. Wilson, D.A. Wilson, M. Peterca, M.R. Imam, V. Percec, Dendronmediated self-assembly, disassembly, and self-organization of complex systems, Chem. Rev. 109 (2009) 6275-6540.

[183] R. Rajasekhar Reddy, K.R. Raghupathi, D.A. Torres, S. Thayumanavan, Stimuli sensitive amphiphilic dendrimers, New J. Chem. 36 (2012) 340-349.

[184] J.F. Kukowska-Latallo, K.A. Candido, Z. Cao, S.S. Nigavekar, I.J. Majoros, T.P. Thomas, L.P. Balogh, M.K. Khan, J.R. Baker, Nanoparticle targeting of anticancer drug improves therapeutic response in animal model of human epithelial cancer, Cancer Res. 65 (2005) 5317-5324.

[185] T.C. Yih, M. Al-Fandi, Engineered nanoparticles as precise drug delivery systems, J. Cell. Biochem. 97 (2006) 1184-1190.

[186] M. Donalisio, M. Rusnati, A. Civra, A. Bugatti, D. Allemand, G. Pirri, A. Giuliani, S Landolfo, D. Lembo, Identification of a dendrimeric heparan sulfate-binding peptide that inhibits infectivity of genital types of human papillomaviruses, Antimicrob. Agents Chemother. 54 (2010) 4290-4299.

[187] T. Dutta, M. Burgess, N.A.J. McMillan, H.S. Parekh, Dendrosome-based delivery of siRNA against E6 and E7 oncogenes in cervical cancer, Nanomedicine 6 (2010) 463-470.

[188] U. Kedar, P. Phutane, S. Shidhaye, V. Kadam, Advances in polymeric micelles for drug delivery and tumor targeting, Nanomedicine 6 (2010) 714-729.

[189] X. Fan, Z. Li, X.J. Loh, Recent development of unimolecular micelles as functional materials and applications, Polym. Chem. 7 (2016) 5898-5919.

[190] V.P. Torchilin, Structure and design of polymeric surfactant-based drug delivery systems, J. Control. Release 73 (2001) 137-172.

[191] N. Nishiyama, K. Kataoka, Current state, achievements, and future prospects of polymeric micelles as nanocarriers for drug and gene delivery, Pharmacol. Ther. 112 (2006) 630-648.

[192] R. Trivedi, U.B. Kompella, Nanomicellar formulations for sustained drug delivery: strategies and underlying principles, Nanomedicine (Lond.) 5 (2010) 485-505.

[193] C. Oerlemans, W. Bult, M. Bos, G. Storm, J.F.W. Nijsen, W.E. Hennink, Polymeric micelles in anticancer therapy: targeting, imaging and triggered release, Pharm. Res. 27 (2010) 2569-2589.

[194] G. Salzano, R. Riehle, G. Navarro, F. Perche, G. De Rosa, V.T. Torchilin, Polymeric micelles containing reversibly phospholipid-modified anti-survivin siRNA: a promising strategy to overcome drug resistance in cancer, Cancer Lett. 343 (2014) 224-231.

[195] G. Gaucher, P. Satturwar, M.-C. Jones, A. Furtos, J.-C. Leroux, Polymeric micelles for oral drug delivery, Eur. J. Pharm. Biopharm. 76 (2010) 147-158.

[196] L. Bromberg, Polymeric micelles in oral chemotherapy, J. Control. Release 128 (2008) 99-112.

[197] D. Šmejkalová, T. Muthný, K. Nešporová, M. Hermannová, E. Achbergerová, G. Huerta-Angeles, M. Svoboda, M. Čepa, V. Machalová, D. Luptáková, V. Velebný, Hyaluronan polymeric micelles for topical drug delivery, Carbohydr. Polym. 156 (2017) 86-96.

[198] M. Lapteva, K. Mondon, M. Möller, R. Gurny, Y.N. Kalia, Polymeric micelle nanocarriers for the cutaneous delivery of tacrolimus: a targeted approach for the treatment of psoriasis, Mol. Pharm. 11 (2014) 2989-3001.

[199] R.W. Lee, D.B. Shenoy, R. Sheel, Micellar nanoparticles: applications for topical and passive transdermal drug delivery, in: V.S. Kulkarni (Ed.), Handbook of Non-invasive Drug Delivery Systems, William Andrew Publishing, Boston 2010, pp. 37-58.

[200] N.R. Mathias, M.A. Hussain, Non-invasive systemic drug delivery: developability considerations for alternate routes of administration, J. Pharm. Sci. 99 (2010) 1-20.

[201] T. Yu, K. Malcolm, D. Woolfson, D.S. Jones, G.P. Andrews, Vaginal gel drug delivery systems: understanding rheological characteristics and performance, Expert Opin. Drug Deliv. 8 (2011) 1309-1322.

[202] Y. Liu, Y.-y. Zhu, G. Wei, W.-y. Lu, Effect of carrageenan on poloxamer-based in situ gel for vaginal use: improved in vitro and in vivo sustained-release properties, Eur. J. Pharm. Sci. 37 (2009) 306-312.

[203] S. Rençber, S.Y. Karavana, Z.A. Senyiğit, B. Eraç, M.H. Limoncu, E. Baloğlu, Mucoadhesive in situ gel formulation for vaginal delivery of clotrimazole: formulation, preparation, and in vitro/in vivo evaluation, Pharm. Dev. Technol. 22 (2017) $551-561$.

[204] J. das Neves, M.F. Bahia, Gels as vaginal drug delivery systems, Int. J. Pharm. 318 (2006) 1-14.

[205] J. Merabet, D. Thompson, R. Saul Levinson, Advancing vaginal drug delivery, Expert Opin. Drug Deliv. 2 (2005) 769-777.

[206] R.R. de Araújo Pereira, M.L. Bruschi, Vaginal mucoadhesive drug delivery systems, Drug Dev. Ind. Pharm. 38 (2012) 643-652.

[207] X.J. Loh, Poly(DMAEMA-co-PPGMA): dual-responsive "reversible" micelles, J. Appl. Polym. Sci. 127 (2013) 992-1000. 
[208] X.J. Loh, J. del Barrio, P.P.C. Toh, T.-C. Lee, D. Jiao, U. Rauwald, E.A. Appel, O.A. Scherman, Triply triggered doxorubicin release from supramolecular nanocontainers, Biomacromolecules 13 (2012) 84-91.

[209] X.J. Loh, S.J. Ong, Y.T. Tung, H.T. Choo, Co-delivery of drug and DNA from cationic dual-responsive micelles derived from poly(DMAEMA-co-PPGMA), Mater. Sci. Eng. C 33 (2013) 4545-4550.

[210] X.J. Loh, M.-H. Tsai, J.D. Barrio, E.A. Appel, T.-C. Lee, O.A. Scherman, Triggered insulin release studies of triply responsive supramolecular micelles, Polym. Chem. 3 (2012) 3180-3188

[211] X.J. Loh, Z.-X. Zhang, Y.-L. Wu, T.S. Lee, J. Li, Synthesis of novel biodegradable thermoresponsive triblock copolymers based on poly[(R)-3-hydroxybutyrate and poly(N-isopropylacrylamide) and their formation of thermoresponsive micelles, Macromolecules 42 (2009) 194-202.

[212] R. Laga, O. Janoušková, K. Ulbrich, R. Pola, J. Blažková, S.K. Filippov, T. Etrych, M. Pechar, Thermoresponsive polymer micelles as potential nanosized cancerostatics, Biomacromolecules 16 (2015) 2493-2505.

[213] C.P. McCoy, C. Brady, J.F. Cowley, S.M. McGlinchey, N. McGoldrick, D.J. Kinnear, G.P. Andrews, D.S. Jones, Triggered drug delivery from biomaterials, Expert Opin. Drug Deliv. 7 (2010) 605-616.

[214] Y. Zhang, Y. Huang, S. Li, Polymeric micelles: nanocarriers for cancer-targeted drug delivery, AAPS PharmSciTech 15 (2014) 862-871.

[215] S. Biswas, P. Kumari, P.M. Lakhani, B. Ghosh, Recent advances in polymeric micelles for anti-cancer drug delivery, Eur. J. Pharm. Sci. 83 (2016) 184-202.

[216] G.A. Husseini, W.G. Pitt, Micelles and nanoparticles for ultrasonic drug and gene delivery, Adv. Drug Deliv. Rev. 60 (2008) 1137-1152.

[217] C.K. Liu, Q. Dou, S.S. Liow, J.N. Kumar, X.J. Loh, Cationic micelles based on polyhedral oligomeric silsesquioxanes for enhanced gene transfection, Aust. J. Chem. 69 (2016) 363-371.

[218] A. El-Aneed, An overview of current delivery systems in cancer gene therapy, J. Control. Release 94 (2004) 1-14.

[219] Z. Teng, Gene delivery for cancer therapy, Curr. Drug Deliv. 11 (2014) 233-242.

220] F. Ordikhani, M. Erdem Arslan, R. Marcelo, I. Sahin, P. Grigsby, J. Schwarz, A. Azab, Drug delivery approaches for the treatment of cervical cancer, Pharmaceutics 8 (2016) 23.

[221] C. Feng, D. Dan, F. Yan, Z. Yong-Hui, L. Shi, C. Ming-Xin, J. Xia-Bin, Anti-tumor activity of biodegradable polymer-paclitaxel conjugated micelle against mice U14 cervical cancers, Chem. Res. Chin. Univ. 28 (2012) 656-661.

[222] D. Luong, P. Kesharwani, H.O. Alsaab, S. Sau, S. Padhye, F.H. Sarkar, A.K. Iyer, Folic acid conjugated polymeric micelles loaded with a curcumin difluorinated analog for targeting cervical and ovarian cancers, Colloids Surf. B: Biointerfaces 157 (2017) 490-502.

[223] J.L. Arias, Drug targeting strategies in cancer treatment: an overview, Mini-Rev. Med. Chem. 11 (2011) 1-17.

[224] Q. Pei, X. Hu, S. Liu, Y. Li, Z. Xie, X. Jing, Paclitaxel dimers assembling nanomedicines for treatment of cervix carcinoma, J. Control. Release 254 (2017) 23-33.

[225] H. You, S. Fu, X. Qin, Y. Yu, B. Yang, G. Zhang, X. Sun, Y. Feng, Y. Chen, J. Wu, A study of the synergistic effect of folate-decorated polymeric micelles incorporating hydroxycamptothecin with radiotherapy on xenografted human cervical carcinoma, Colloids Surf. B: Biointerfaces 140 (2016) 150-160.

[226] M.F. Bachmann, G.T. Jennings, Vaccine delivery: a matter of size, geometry, kinetics and molecular patterns, Nat. Rev. Immunol. 10 (2010) 787-796.

[227] G.T. Jennings, M.F. Bachmann, The coming of age of virus-like particle vaccines, Biol. Chem. 389 (2008) 521-536.

[228] L. Zhao, A. Seth, N. Wibowo, C.-X. Zhao, N. Mitter, C. Yu, A.P.J. Middelberg, Nanoparticle vaccines, Vaccine 32 (2014) 327-337.

[229] S.C. Semple, A. Akinc, J. Chen, A.P. Sandhu, B.L. Mui, C.K. Cho, D.W.Y. Sah, D. Stebbing, E.J. Crosley, E. Yaworski, I.M. Hafez, J.R. Dorkin, J. Qin, K. Lam, K.G. Rajeev, K.F. Wong, L.B. Jeffs, L. Nechev, M.L. Eisenhardt, M. Jayaraman, M. Kazem, M.A. Maier, M. Srinivasulu, M.J. Weinstein, Q. Chen, R. Alvarez, S.A. Barros, S. De, S.K. Klimuk, T. Borland, V. Kosovrasti, W.L. Cantley, Y.K. Tam, M. Manoharan, M.A. Ciufolini, M.A. Tracy, A. de Fougerolles, I. MacLachlan, P.R. Cullis, T.D. Madden, M.J. Hope, Rational design of cationic lipids for siRNA delivery, Nat. Biotechnol. 28 (2010) 172-176.

[230] V. Manolova, A. Flace, M. Bauer, K. Schwarz, P. Saudan, M.F. Bachmann, Nanoparticles target distinct dendritic cell populations according to their size, Eur. J. Immunol. 38 (2008) 1404-1413.

[231] F. Zabel, T.M. Kündig, M.F. Bachmann, Virus-induced humoral immunity: on how B cell responses are initiated, Curr. Opin. Virol. 3 (2013) 357-362.

[232] F.T. Cutts, S. Franceschi, S. Goldie, X. Castellsague, S. de Sanjose, G. Garnett, W.J. Edmunds, P. Claeys, K.L. Goldenthal, D.M. Harper, L. Markowitz, Human papillomavirus and HPV vaccines: a review, Bull. World Health Organ. 85 (2007) 719-726.

[233] A.C. Gomes, M. Mohsen, M.F. Bachmann, Harnessing nanoparticles for immunomodulation and vaccines, Vaccine 5 (2017) 6.

[234] U. Hani, R.A. Osmani, R.R. Bhosale, H.G. Shivakumar, P.K. Kulkarni, Current perspectives on novel drug delivery systems and approaches for management of cervical cancer: a comprehensive review, Curr Drug Targets. 17 (2016) 337-352. 